\title{
Innovative Nanotechnology a Boon for Fight Against Pandemic COVID-19
}

\author{
Ibrahim Aminu Shehu ${ }^{1 *}$, Nura Mustapha Auwal ${ }^{1}$, Muhammad Kabir Musa ${ }^{2}$, \\ Abubakar Mukhtar ${ }^{1}$, Mashahudu Sha'arani Yusuf ${ }^{1}$, Anees Ashir Yau ${ }^{1}$, Murtala Muhammad ${ }^{1}$, \\ Yusuf Baba Dala ${ }^{1}$, Salisu Abdullahi Sani ${ }^{1}$, Mahmoud Seed Ahmad ${ }^{1}$ and Mojahidul Islam ${ }^{1}$ \\ ${ }^{1}$ Sharda University, Noida, India, ${ }^{2}$ Ahmadu Bello University, Zaria, Nigeria
}

OPEN ACCESS

Edited by:

Alessandro Chiolerio,

Italian Institute of Technology (IIT), Italy

Reviewed by:

Tsukuru Minamiki,

National Institute of Advanced Industrial Science and Technology

(AIST), Japan

Xueqian Fang,

Shijiazhuang Tiedao University, China

*Correspondence:

Ibrahim Aminu Shehu

ibrahimaminushehu@gmail.com

Specialty section:

This article was submitted to

Nanodevices,

a section of the journa Frontiers in Nanotechnology

Received: 09 January 2021 Accepted: 14 June 2021

Published: 29 June 2021

Citation:

Shehu IA, Auwal NM, Musa MK, Mukhtar A, Yusuf MS, Yau AA, Muhammad M, Baba Dala Y, Sani SA,

Ahmad MS and Islam M (2021) Innovative Nanotechnology a Boon for Fight Against Pandemic COVID-19.

Front. Nanotechnol. 3:651308. doi: 10.3389/fnano.2021.651308
COVID - 19 is a contagious disease caused by severe acute respiratory syndrome (SARSCoV2). The rate at which COVID - 19-virus spread from epidemic to pandemic within a short period is quite alarming. As of July 2020, the Dashboard of the World Health Organization (WHO) recorded over 15 million COVID - 19 cases across 213 countries, with mortality of over 620,000. The governments and healthcare agencies responsible for mitigating the virus's spread have adopted several strategies to end the pandemic. However, all hands were on deck to establish the standard treatment modalities of SARS-CoV-2 through inventing new drugs, vaccine candidates, or repurposing the existing medicines and robust diagnostic tools, in addition to other technological innovations. Therefore, nanotechnology's employment would play a vital role in bringing multidisciplinary ways of developing affordable, reliable, and powerful tools for diagnosis, in addition to personal protection and effective medicines. Additionally, nanosensors' application would significantly aid the diagnoses of the COVID-19 even on asymptomatic patients, and thus would be an essential means for determining its prevalence. Likewise, nanoscale fibers can optimize personal equipment protection and allow their reusability for medical and economic benefits. Accordingly, the literature was intensively reviewed by searching for the combinations of the research keywords in the official scientific databases such as Science Direct, PubMed, and Google Scholar. Hence, this research highlighted the perspective contributions of nanotechnology in the war against the COVID-19 pandemic.

Keywords: COVID-19, diagnosis, nanaoparticles, nanomaterials, vaccines, nanomedicines

\section{INTRODUCTION}

June Almeda first identified the coronavirus family in 1963 while working at the Ontario Cancer Institute in Toronto, Canada. The Scottish scientist saw some greenish dots embedded in a spike-like structure under an electron microscope called corona in the Latin term, which means crown in English (History and Culture, 2020). Viruses have been characterized by their pathogenicity and rapid transmission from zoonotic to human beings, which has caused a wide range of diseases. However, it was not confirmed whether or not the virus was zoonotic (Shereen et al., 2020). Severe Acute Respiratory Syndrome (SARS-CoV) was the first outbreak of coronavirus in Spain in 2003 (Xie and Chen, 2020). While the Middle East Respiratory Syndrome (MERS) was the second pandemic that broke out in Saudi Arabia in 2012. Where it causes a serious range of illnesses in the Middle East part of Asia (Cao et al., 2020). Recently, the outbreak of the COVID-19 pandemic in China's Wuhan market in December 2019 was first diagnosed as a pneumonia of unknown etiology (Biomedical and 
Pharmaceutical Sciences, 2020). However, the genomic sequence investigation revealed its $80 \%$ genetic resemblance to SARS-CoV. Consequently, the "International Committee on Taxonomy of Viruses" (ICVT) named it SARS-CoV-2 (Siordia, 2020). Moreover, COVID-19 identified as a single-stranded RNA virus with an oval like shape and enveloped within a crownlike structure of 60-140 nm in diameter (Woo et al., 2009; Walls et al., 2020).

At present, the actual mechanism through which COVID-19 transmit is under investigation (Majumdar et al., 2020). However, Liu J et al. reported the transmission from person to person by direct body contact or droplet nucleus (aerosols) of the infected person. Indirect transmission by contact with contaminated surfaces is possible under certain conditions. Similarly, the possibility of fecal-oral infection was evident following the detection of COVID-19 in fecal swabs of both positively and negatively testes people (Zhang et al., 2020a; Chan et al., 2020; Liu et al., 2020; Xiao et al., 2020). Perhaps, some reports have suggested that respiratory droplets are the primary sources of transmission; in this instance, even asymptomatic patients could be able to transmit the COVID-19 virus without their consent. The droplet size may alter the means of the viral spread; the droplets of $20 \mu \mathrm{m}$ and more might be influenced by gravity, making it falls to the objects. While the smaller ones that have a diameter of less than 5-10 $\mu \mathrm{m}$ may evaporate to air and suspend for more than $12 \mathrm{~h}$, potentiating the possibility of airborne transmission (Ge et al., 2020; WHO, 2020). Therefore, Jayaweera $\mathrm{M}$ et al., reported that the infected person's coughs or sneezes could transmit airborne particles to a distance of more than 20 feet (Bahl et al., 2020; Jayaweera et al., 2020; Yen et al., 2020).

Currently, the treatment of COVID-19 remains challenging in a global healthcare setting (Rojas et al., 2020).

Moreover, scientists have been working around the clock to develop either novel or repurpose drugs and vaccines that could treat the virus entirely or provide prophylaxis against it (Zhang et al., 2020b) since there are no approved clinical protocols and vaccines or medications to treat the infection (Wu et al., 2020). Therefore, establishing a reliable assay that can accurately diagnose SARS-CoV-2 in a suspected sample within a short period is equally needed (Ozma et al., 2020). World Health Organization (WHO) recommended the international community to be conducting a wide-range of COVID-19 diagnostic tests to reduce the number of undetected cases (WHO, 2011). However, setting up the proper testing protocol of COVID-19 is essential for better understand the disease, its prevalence, and preventive measures (Joshi and Bhansali, 2008; Dicker et al., 2018). In this challenging time, nanotechnology's employment can significantly open pipelines that will provide a breakthrough in the diagnosis, mitigation, prevention, and management of SARS-CoV-2 infection (Sivasankarapillai et al., 2020). According to the available literature, nano-formulations of various metallic and metallic oxides have been used to inactivate and prevent the transmission of different virus species ( $\mathrm{Li}$ et al., 2015). Nowadays, Synthetic nanofibres are used to make reusable facemasks and Personal Protective Equipment PPE with the highest protection affinity (Moin, 2020). Besides, several rapid diagnostic tests of high precision and accuracy have been developed using different nanomaterials to detect viral presence within a few minutes (Zainol Rashid et al., 2020). Also, theranostic NPs and optical biosensors can reliably trace the viral genome present at a minute in the sample. Similarly, nano-bio-interaction can serve as a powerful tool to elucidate the viral life cycle in the host cell, facilitating the identification of new molecules that could interfere with vital viral targets (Morse et al., 2020). Researchers have developed small and ultra-sensitive single nanowire biosensors that have gained much attention due to their ultra-sensitive efficacy in pathogen detection (Joshi and Bhansali, 2008). Silver-based nanoparticles (AgNPs) have several biomedical applications ranging from drug delivery optimization to low toxicity antimicrobial properties (Naqvi et al., 2013; Burdușel et al., 2018). Therefore, the concept of nanotechnology can serve as an alternative way to adopt in the global fight against the COVID-19 pandemic (Kim et al., 2020a). However, more research is needed on nanotechnology to explore its full potentiality in fighting the virus. This research highlighted the significant contributions of nanotechnology in preventing, diagnosing, and treating the pandemic COVID-19 infection.

\section{Cellular Bio-Interaction of SARS-COV-2}

All coronaviruses contain a specific region in ORFI downstream that encodes viral replication, spikes formation, and nucleocapsid. These spikes-glycoprotein located at the outer part of the virus are responsible for the virus's attachment with the host's cells (Yan et al., 2020). It also contains a receptor-binding domain (RBD), which acts as a binding pocket that enables the virus to bind to several sections at a time. Other coronaviruses are recognized and bind to carbohydrates or aminopeptidases as a critical receptor for entry into the human body, while SARS-CoV-2 binds to ACE2 with the help of exopeptidases, which catalyzes the reaction (Baig et al., 2020). However, the mechanism depends on the cellular proteases like human airway trypsin-like protease (HAT), transmembrane protease serine 2 (TMPRSS2), and cathepsins. The SARS-CoV-2-spike protein exhibits van der walls force of attraction with the RBD and the lysine residue of angiotensin-converting enzyme ACE-2 recognizes the glutamate residue in the host's RBD region (ACE-2) (Tahir ul Qamar et al., 2020). The life cycle begins when the Spike protein of the virus binds to the cellular receptor of ACE2 (Devaux et al., 2020). A conformational change occurs, which facilitates viral fusion with the cell membrane through the endosomal pathway. The virus releases RNA into the host's cell and then translated it into the viral replicas pyrophosphatase (inorganic)-1a (ppala) and pyrophosphatase (inorganic)-1b (ppalb), which cleaved into tiny pieces by viral proteinases (Elfiky, 2020). The enzyme polymerase produces a series of subgenomic and mRNA discontinuous transcription and then finally translated into relevant viral protein. The proteins are assembled into the Golgi apparatus's virions and endoplasmic reticulum. The replicated viruses were then transported into vesicles and subsequently released out of the 


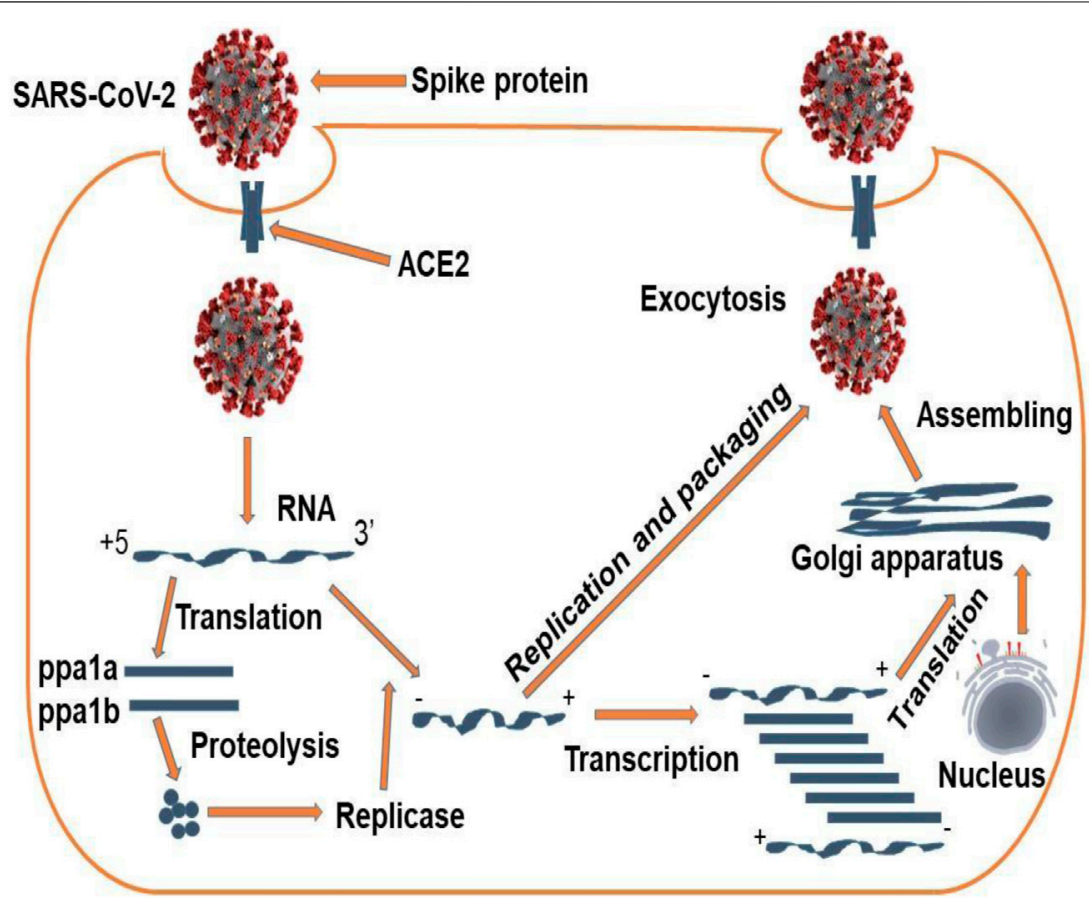

FIGURE 1 | Life circle of SARS-CoV-2 in a host's cell.

TABLE 1 | Illustration of antiviral nanoparticles that inactivate different types of Viruses.

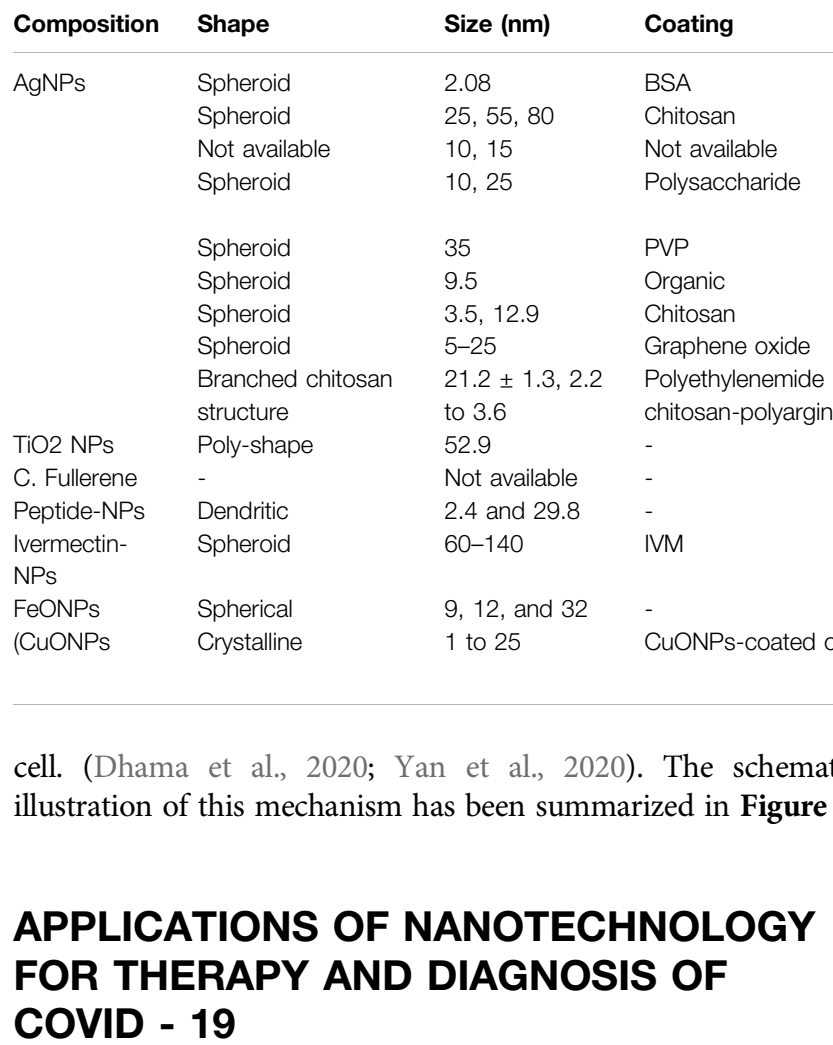

Nanotechnology is a powerful weapon for mitigating the fatality and mortality of coronaviruses (Zhou et al., 2020). It could exert its applicability both externally and internally of the host body. Many evidence-based studies have previously proved the antiviral effectiveness of many forms of nanotechnology-based formulations, especially on the respiratory tract and Human Immunodeficiency Virus (HIV) infections (Jackman et al., 2016; Yadavalli and Shukla, 2017). Nanotechnology and nanomaterials have been widely explored as diagnostic and therapeutic agents in managing infectious diseases and could be applied to COVID-19 treatment (Adesina and Akala, 2015). The application of nanotechnology in diagnosing, mitigating, and 
managing many SARS-CoV-2 related viruses has been summarized in Table 1.

\section{Plasmonic Photothermal Effect on COVID-19}

$\mathrm{Ag}$ and AuNPs or nanotubes have been reported to induce a "Plasmonic photothermal effect" that could be achieved by subjecting metals to intense solar irradiation, which makes them emit light capable of viral inactivation at an optimum wavelength (Govorov and Richardson, 2007). The AuNPs are preferable to be used as a Plasmonic photothermal in-activator because of their lesser toxicity than AgNPs (Loeb et al., 2018). However, the concept of "Pulsed-laser irradiation systems" was found to have shown the desirable selectivity in viral inactivation. Loeb et al. demonstrated the case study that examined photonic gold nanorods' effectiveness in "Murine Leukemia Virus" inactivation by striking the $250 \mu \mathrm{L}$ viral sample with $805 \mathrm{~nm}$ fs pulses at the energy of $7.5 \mathrm{mj}$ at a repeated rate of $1 \mathrm{KHz}$ for $10 \mathrm{~s}$ under the temperature of $22^{\circ} \mathrm{C}$. The result showed that photonic gold nanotubes significantly reduced viral infectivity to less than 3.7-log, reducing the virus's selectivity with high precision by inducing no effect on co-inoculated antibodies (Nazari et al., 2017).

\section{Nano-Biosensors and Their Applications in COVID-19 Diagnosis}

The proper diagnosis is critical in tackling COVID-19 pandemics infection (Zhuang et al., 2020). The vigorous testing operations of approximately 20,000 people run daily in some countries, including South Korea conduct (Morales-Narváez and Dincer, 2020). While the German laboratories run about 400,000 coronavirus tests every week (Richardson et al., 2020). This comprehensive testing possibly attributes to their emergence among the most prosperous countries that record the lowest COVID-19 mortality rate worldwide (Hussain et al., 2020). However, the biosensor device is the technology behind this massive testing ability. Moreover, understanding the sensing mechanism in nano-dimensions is essential in developing efficient biosensors (Das et al., 2016). Biosensors have currently been employed to analyze the microorganism's biological structure or detect biomolecules present at a minimum concentration in the sample (Polizzi, 2019). These biosensors are made up of three components, namely (A) a "sensing bioreceptor" (signal producer) (B) "signal transducer," and (C) a "reader device” (Li et al., 2020a; Aminu Shehu and Mukhtar, 2020). Perhaps, among the latest biosensing diagnostic devices, a field-effect transistor (FET)-based biosensor offers many benefits. Including the ability to conduct extremely responsive and rapid tests using small amounts of analyses (Li et al., 2020a), and it became beneficial for medical diagnosis (Hsiao et al., 2009). Nevertheless, graphene shows the extraordinary properties of having a wider 3-D area, high carrier mobility, and electronic conductivity (Cooper et al., 2012) that make it a suitable means for various sensing platforms (Geim and Novoselov, 2007). However, Graphene-based (FET) biosensors can detect minute changes in the environment and create an ideal sensing atmosphere for ultra- sensitivity. Therefore, graphene-based FET-technology is very appealing for sensitive immunological diagnostic applications (Lei et al., 2017; Zhou et al., 2017). The surface receptors of biosensors are similar to the specific RNA sequence of COVID-19, making it easier for the biosensors to recognize the presence of SARS-CoV-2 in the suspected sample. (Seo et al., 2020; Aminu Shehu and Mukhtar, 2020) As a result of the inconvenience associated with the real-time polymerase chain reaction (RT-PCR) assay, this includes the possibility of a false result. Scientists have conducted several studies to find the right alternatives, among others; Swiss scientists have developed a "dual-functional plasmon biosensor" that works by applying two-dimensional (2-D) gold nanoislands (AuNIs) and plasmonic photothermal (PPT) effects. The sensor detects COVID-19 at a low concentration (0.22 pM) in the suspected sample (Singh, 2014; Nguyen and Sim, 2015). However, the sensor recognizes the SARS-CoV-2 RNA in high precision by measuring the refractive index's change because of the interaction between the SARS-CoV-2-RNA and the DNA receptors incorporated in gold nanoislands of the biosensors, following the temperature changes due to the plasmonic photothermal effect (American Chemical Society, 2020; Qiu et al., 2020). Besides, J. Wang et al. have shown that SARS-CoV-2 can be detected precisely and quickly using a dual-functional Plasmon system. Therefore, the "localized surface Plasmon Resonance" (LSPR)-based biosensors could be a reliable tool for COVID-19 diagnostics. The researcher also demonstrated that SARS-CoV-2 could be detected precisely and quickly using a dual-functional Plasmon system. Therefore, the "localized surface Plasmon Resonance" (LSPR)-based biosensors could be a reliable tool for COVID-19 diagnostics (Jin et al., 2020a). Moreover, attention has been paid to paper-based biosensors' point of-care testing' in "point-of-care testing" because of their cheapness, practicality, and excellent biopharmaceutical properties compared to chipbased biosensors (Hu et al., 2017; Böhm et al., 2018; Choi et al., 2019). However, V.X. Ting et al. have developed a Gold NPs based biosensor for rapid detection of COVID-19; the biosensor uses colorimetric techniques and enables the detection of SARS-COV-2 nucleic acid present at a minute $(100 \mathrm{fM})$ in a particular sample within $5 \mathrm{~min}$ (Aldewachi et al., 2018; Zhao et al., 2020a). S.A. Layqah, et al. designed the Au-NP immunosensor to detect COVID-19, and the biosensor was found to have used the spike protein as a biomarker. The biosensor was shown to accurately identify the COVID-19 in less than $20 \mathrm{~min}$ (Layqah and Eissa, 2019). Graphene oxide nanoparticles (GO-NPs) have been determined to inhibit the cellular entrance of COVID-19 by blocking the viral spike protein (Ahmed et al., 2020a). Some studies have shown the inhibitory effect of silver-graphene nanoparticles against SARS-CoV-2 (Weiss et al., 2020). against the virus COVID-19 (Lin et al., 2019; Choi, 2020). As summarized in Table 2 and Figure 2.

\section{COVID-19 Rapid Testing Using Different Nanoparticles}

Real-time polymerase chain reaction (RT-PCR) is the conventional procedure for laboratory diagnosis of COVID-19, as per the WHO guidelines (Jin et al., 2020b). This approach does 
TABLE 2 | Summarized the application of various nanomaterial in the sensing system of SARS-CoV and other related viruses.

\begin{tabular}{|c|c|c|c|c|c|}
\hline Biosensors & Nanomaterial & Viruses & $\begin{array}{l}\text { Mechanism for } \\
\text { detection }\end{array}$ & Limitations & References \\
\hline $\begin{array}{l}\text { Electrochemical bio/ } \\
\text { immunosensor }\end{array}$ & Au/Ag nanoparticle & $\begin{array}{l}\text { Influenza a virus } \\
\text { M1 parainfluenza } \\
\text { Rhinovirus the middle } \\
\text { east respiratory } \\
\text { syndrome (MERS) } \\
\text { SARS-CoV-2 }\end{array}$ & $\begin{array}{l}\text { To determine the variation of } \\
\text { electrical conductivity by } \\
\text { detecting the virus in the saliva } \\
\text { sample }\end{array}$ & $\begin{array}{l}\text { Large-scale availability and it } \\
\text { require technical know-how }\end{array}$ & $\begin{array}{l}\text { Mizuta et al. (2016), } \\
\text { Zhang et al. (2018), Liu } \\
\text { et al. (2019) }\end{array}$ \\
\hline \multirow[t]{2}{*}{$\begin{array}{l}\text { Optical Bio/ } \\
\text { Immunosensor }\end{array}$} & $\begin{array}{l}\text { Gold nanoparticles } \\
\text { Au NPs }\end{array}$ & $\begin{array}{l}\text { SARS-CoV; H5N1 } \\
\text { influenza virus; }\end{array}$ & Optical & $\begin{array}{l}\text { The devices are expensive. The } \\
\text { fluorescent signal gets weak } \\
\text { quickly }\end{array}$ & $\begin{array}{l}\text { Chen and Yin (2014), } \\
\text { Pereira et al. (2014), } \\
\text { Sharifi et al. (2019) }\end{array}$ \\
\hline & & $\begin{array}{l}\text { Human } \\
\text { Adenovirus; } \\
\text { Respiratory } \\
\text { Syncytial virus (RSV); } \\
\text { influenza }\end{array}$ & $\begin{array}{l}\text { Immunosensor uses the } \\
\text { transduction of the light signal to } \\
\text { recognize the analytic sample }\end{array}$ & - & - \\
\hline Thermal biosensor & $\begin{array}{l}\text { Quantum dots/Au } \\
\text { nanoparticles }\end{array}$ & $\begin{array}{l}\text { SARS-CoV, MERS } \\
\text { SARS-CoV-2 }\end{array}$ & $\begin{array}{l}\text { To measure the heat energy } \\
\text { released or absorbed from a given } \\
\text { sample }\end{array}$ & $\begin{array}{l}\text { The biomolecule turned into a } \\
\text { colloid, then to nanocrystal's }\end{array}$ & $\begin{array}{l}\text { Campuzano et al. } \\
\text { (2019), Faria and } \\
\text { Zucolotto (2019), Choi } \\
\text { et al. (2020) }\end{array}$ \\
\hline $\begin{array}{l}\text { Piezoelectric } \\
\text { immunosensor }\end{array}$ & $\begin{array}{l}\text { Gold nanoparticles } \\
\text { (AuNPs) }\end{array}$ & $\begin{array}{l}\text { SARS-CoV, influenza } \\
\text { Virus; adenovirus; } \\
\text { Rsv; MERS } \\
\text { MERS }\end{array}$ & $\begin{array}{l}\text { Based on sound vibration called } \\
\text { acoustics biosensor }\end{array}$ & $\begin{array}{l}\text { It is challenging to determine the } \\
\text { substance in a given solution }\end{array}$ & $\begin{array}{l}\text { Wu (2007), Raghav and } \\
\text { Srivastava (2016), } \\
\text { Suresh et al. (2018) }\end{array}$ \\
\hline Plasmonic & $\begin{array}{l}\text { Gold nanoparticles } \\
\text { (AuNPs)/carbon } \\
\text { nanotube }\end{array}$ & COVID-19 & $\begin{array}{l}\text { To detect the nucleocapsid }(\mathrm{N}) \\
\text { protein in the saliva sample, an } \\
\text { essential protein of the COVID-19 }\end{array}$ & $\begin{array}{l}\text { It requires substantial financial } \\
\text { support, BSLIII laboratory } \\
\text { infrastructure, and industrial } \\
\text { partner }\end{array}$ & Murugan et al. (2020) \\
\hline Fiber-optic & - & - & - & - & - \\
\hline Absorbance & - & - & - & - & - \\
\hline Biosensor (P-FAB) & - & - & - & - & - \\
\hline $\begin{array}{l}\text { Colorimetric paper- } \\
\text { based biosensor }\end{array}$ & $\begin{array}{l}\text { Gold nanoparticles } \\
\text { (AuNPs) }\end{array}$ & $\begin{array}{l}\text { MERS SARS-CoV, } \\
\text { SARS-CoV-2 }\end{array}$ & $\begin{array}{l}\text { To convert signals from pathogen } \\
\text { to produce an amplified } \\
\text { colorimetric readout }\end{array}$ & $\begin{array}{l}\text { The presence of low sensitivity, } \\
\text { instability in the environment, } \\
\text { and high cost of production }\end{array}$ & Yusuf et al. (2020) \\
\hline $\begin{array}{l}\text { Chip-based } \\
\text { biosensors }\end{array}$ & $\begin{array}{l}\text { Gold nanoparticles } \\
\text { (AuNPs) }\end{array}$ & SARS-COV-2 & $\begin{array}{l}\text { Based on nucleic acid detection } \\
\text { by the colorimetric signal of loop- } \\
\text { mediated isothermal amplification } \\
\text { (LAMP) }\end{array}$ & $\begin{array}{l}\text { It has a complicated fabrication } \\
\text { process. It requires highly skilled } \\
\text { personnel. There is a lack of } \\
\text { quantification }\end{array}$ & $\begin{array}{l}\text { Tymm et al. (2020), Jin } \\
\text { et al. (2020b) }\end{array}$ \\
\hline
\end{tabular}

not offer solutions to nonsuit ability for on-site detection and procedure for the Isolation of lengthy nucleic acids. In addition to this, a fake-negative report is also unavoidable due to many factors, like faulty reagents, inaccurate sampling techniques, as well as the lower sampling viral load (Li et al., 2020b). Scientists have currently developed a novel COVID-19 testing protocols that can visually detect coronavirus presence within a period of 10 min (Balfour, 2020). However, some researchers from the University Of Maryland, School of Medicine (UMSOM), United States, analyzed the samples obtained from the suspected patient's nasal swab and saliva, using a highly sensitive molecule incorporated with gold nanoparticles (AuNPs) to detect the COVID-19 viral RNA. On examination, the samples that contained the viral antigen reacted with gold nanoparticles (AuNPs) and changed the color of the liquid reagent from purple to dark blue, while the negative viral-antigen samples retain their purple colors (Balfour, 2020). In addition, these visual color changes could be the simplest means of COVID-19 detection, just as they were used in the diagnosis of HIV, influenza viruses et al. Similarly, the reaction complex that occurs between AuNPs-coupled antibodies and the enzyme-linked immunosorbent assay (ELISA) in the presence of viral antigen results in a visual color change from red to blue, and could therefore be a promising alternative for coronavirus 2019 detection (Lagier et al., 2020). Chao Huang et al. performed a rapid diagnostic test using colloidal gold nanoparticle-based lateral-flow "AuNPLF" strips. They have tested the samples of both positive and negative COVID - 19and compared the results with the conventional diagnostic approach of real-time polymerase chain reaction (RT-PCR) (Huang et al., 2020a). The study concluded that a colloidal gold nanoparticle-based lateral-flow (AuNP-LF) assay had owned an excellent IgM detection property from a minute sample quantity $(10-20 \mu \mathrm{L})$ shows high specificity to COVID -19 detection within a short period of about $15 \mathrm{~min}$ (Huang et al., 2020a). Moreover, the techniques became a breakthrough for longer diagnostic procedures and being simple, easy to handle, and reliable to confirm the presence of SARS-CoV-2 (Huang et al., 2020a). Meanwhile, J. Ying et al., have demonstrated an immuno-chromatographic assay using AuNPs of varying sizes $(14,16,35$, and 38$) \mathrm{nm}$, and assess their conjugation affinities to antibodies under different 


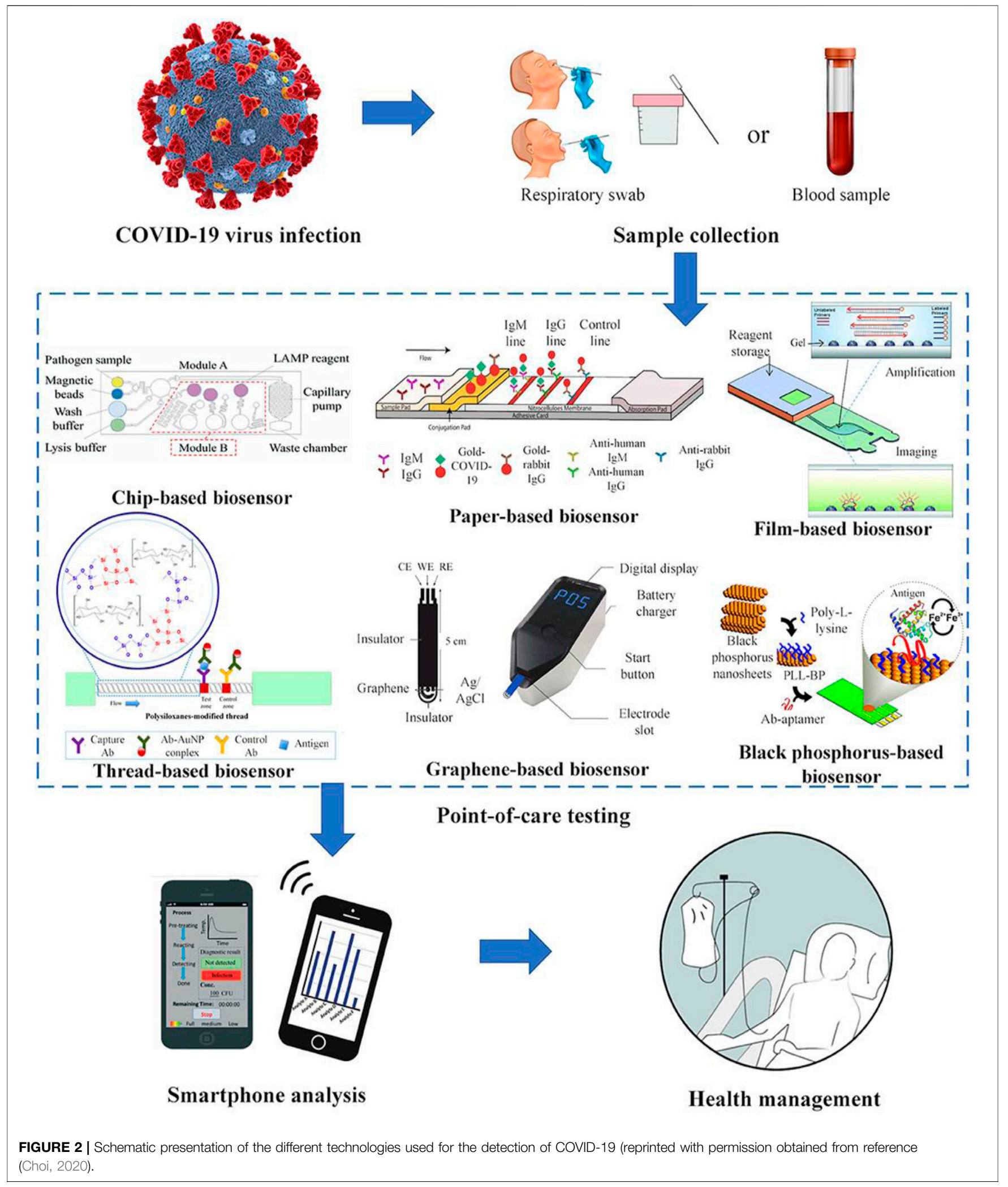

environmental PH. In conclusion, the author discovered that the size of AuNPs, optimum PH, and antibody concentration in the sample are the factors that determine the effectiveness of the diagnosis (Lou et al., 2012). Therefore, desirable antibodylabeled-AuNPs could serve as a standpoint for the clinical diagnosis of COVID-19. Nevertheless, the South Korean 
TABLE 3 | Nanotechnology-based vaccines.

\begin{tabular}{|c|c|c|c|c|c|c|}
\hline Sponsor & Vaccine & Description & Stage & Ct number & $\begin{array}{c}\text { Expected } \\
\text { date } \\
\text { of } \\
\text { completion }\end{array}$ & References \\
\hline $\begin{array}{l}\text { Modern, national } \\
\text { institutes of } \\
\text { health }\end{array}$ & mRNA-1273 & $\begin{array}{l}\text { mRNA } \\
\text { encapsulated in } \\
\text { lipid NPs, the } \\
\text { trial was } \\
\text { conducted on } \\
\text { 18-55 years } \\
\text { healthy } \\
\text { volunteers for } \\
63 \text { days }\end{array}$ & $\begin{array}{l}\text { Phase } \\
1\end{array}$ & NCT04283461 & $\begin{array}{l}\text { April 16, } \\
2020\end{array}$ & $\begin{array}{l}\text { Amanat and } \\
\text { Krammer } \\
\text { (2020), } \\
\text { Moderna } \\
\text { (2020b) }\end{array}$ \\
\hline $\begin{array}{l}\text { Pfizer/BioNTech } \\
\text { and CureVac }\end{array}$ & INO-4800 & $\begin{array}{l}\text { A randomized } \\
\text { clinical study } \\
\text { involved } 3 \text { age } \\
\text { groups (65-85, } \\
18 \text { to } 55 \text { and } \\
18-85 \text { years of } \\
\text { age) conducted } \\
\text { in } 3 \text { stages, } \\
\text { each consist of } \\
15 \text { participants } \\
\text { in which the } \\
\text { vaccine } \\
\text { administered in } \\
\text { low moderate } \\
\text { and high } \\
\text { doses, } \\
\text { respectively }\end{array}$ & $\begin{array}{l}\text { Phase } \\
\text { I/II trials }\end{array}$ & NCT04368728, NCT04380701 & $\begin{array}{l}\text { Jan. 23, } \\
2023\end{array}$ & $\begin{array}{l}\text { Ahmed et al. } \\
\text { (2020b) }\end{array}$ \\
\hline $\begin{array}{l}\text { The university of } \\
\text { oxford and } \\
\text { AstraZeneca }\end{array}$ & ChAdOx1 & $\begin{array}{l}\text { ChAdOx1 has } \\
\text { been } \\
\text { administered to } \\
6 \text { rhesus } \\
\text { macaques } \\
\text { exposed to } \\
\text { heavy doses of } \\
\text { COVID-19. The } \\
\text { chimpanzee } \\
\text { adenovirus } \\
\text { vector vaccine } \\
\text { is dependent } \\
\text { on the vaccine. } \\
\text { The vaccine } \\
\text { should not be } \\
\text { used infection } \\
\text { avoidance, } \\
\text { even if it } \\
\text { decreased the } \\
\text { severity of the } \\
\text { diseases }\end{array}$ & $\begin{array}{l}\text { Phase I } \\
\text { clinical } \\
\text { trial }\end{array}$ & NCT04324606 & April 2020 & $\begin{array}{l}\text { Author } \\
\text { Anonymous } \\
(2017) \\
\text { Novavax } \\
(2020)\end{array}$ \\
\hline $\begin{array}{l}\text { CanSino } \\
\text { biological inc. } \\
\text { and beijing } \\
\text { institute of } \\
\text { biotechnology }\end{array}$ & Ad5-nCoV & $\begin{array}{l}\text { "mRNA-1273" } \\
\text { produced } \\
\text { antibody titters } \\
\text { more then the } \\
\text { levels observed } \\
\text { in convalescent } \\
\text { once, in every } 8 \\
\text { initial } \\
\text { participants } \\
\text { between the } \\
25-100 \text { Mg } \\
\text { dose cohorts of } \\
\text { the phase I trial }\end{array}$ & $\begin{array}{l}\text { Phase } \\
\text { I/II trials }\end{array}$ & NCT04398147NCT04341389NCT0431312 & $\begin{array}{l}\text { May 18, } \\
2020\end{array}$ & $\begin{array}{l}\text { U. S. } \\
\text { National } \\
\text { Library of } \\
\text { Medicine, } \\
\text { (2020b) }\end{array}$ \\
\hline & ChiCTR2000031809,ChiCTR2000032459 & & & NCT04383574, NCT04352608 & & \\
\hline
\end{tabular}


TABLE 3 | (Continued) Nanotechnology-based vaccines.

\begin{tabular}{|c|c|c|c|c|c|c|}
\hline Sponsor & Vaccine & Description & Stage & Ct number & $\begin{array}{c}\text { Expected } \\
\text { date } \\
\text { of } \\
\text { completion }\end{array}$ & References \\
\hline $\begin{array}{l}\text { China national } \\
\text { pharmaceutical } \\
\text { group } \\
\text { (sinopharm), in } \\
\text { association with } \\
\text { the "wuhan } \\
\text { institute of } \\
\text { biological } \\
\text { products" and } \\
\text { "beijing institute } \\
\text { of biological } \\
\text { products }\end{array}$ & & $\begin{array}{l}\text { The latest } \\
\text { investigation on } \\
\text { live attenuated } \\
\text { vaccines } \\
\text { provide partial } \\
\text { or complete } \\
\text { protection in } \\
\text { macaques } \\
\text { rhesus and } \\
\text { now being } \\
\text { tested clinical } \\
\text { trials }\end{array}$ & $\begin{array}{l}\text { Phase } \\
\text { I/II trials }\end{array}$ & & $\begin{array}{l}\text { April 11, } \\
2020\end{array}$ & $\begin{array}{l}\text { Among et al. } \\
(2020) \text {, Reiss } \\
(2020)\end{array}$ \\
\hline
\end{tabular}

TABLE 4 | Status of some nanomedicine and vaccines in a clinical trial against COVID19.

\begin{tabular}{|c|c|c|c|c|}
\hline $\begin{array}{l}\text { S/ } \\
\text { No }\end{array}$ & Candidate & Clinical trial & Sponsor & References \\
\hline 1 & AV-COVID- 19 & Phase I/II & AIVITA biomedical, inc & $\begin{array}{l}\text { Sheng and Christopher } \\
\text { (2016) }\end{array}$ \\
\hline 2 & $\begin{array}{l}\text { BNT162a, BNT1621b,BNT162b2, } \\
\text { BNT162c2 }\end{array}$ & Phase I/II & Biotech RNA pharmaceuticals GmbH & $\begin{array}{l}\text { Chauhan et al. (2020) } \\
\text { Thanh Le et al. (2020) }\end{array}$ \\
\hline & Ad5-nCoV & Phase1 & CanSinoBiologics & Hua and Wu (2018) \\
\hline 3 & NVX-CoV2373 & Phase $1 / \|$ & Novavax & Moderna (2020b) \\
\hline 4 & CTII-nCoV & Phase I/II & $\begin{array}{l}\text { Institute of biotechnology, "academy of military medical sciences", } \\
\text { PLA of China }\end{array}$ & Huang et al. (2020b) \\
\hline 5 & ChAdOx1 & Phase $1 / I 1$ & Jenner institute-the university of oxford & \\
\hline 6 & INO-4800 & Phase I & Inovio pharmaceuticals & \\
\hline 7 & SCB-2019 trimeric S-subunit protein & Phase $|/| I$ & Clover biopharmaceuticals AUS pty Itd & \\
\hline 8 & INO-4800 & Phase I & Inovio pharmaceuticals & Tebas et al. (2021) \\
\hline 9 & Oral bacTRL- spike & $\begin{array}{l}\text { Phase I } \\
\text { recruiting }\end{array}$ & Symvivo corporation & Lara et al. (2011) \\
\hline 10 & mRNA & Phase III & Pfizer and BioNTech (approved for emergency used) & Thi et al. (2015) \\
\hline 11 & mRNA-1273 & Phase III & Moderna (approved for emergency used) & Nam et al. (2003) \\
\hline 12 & LV- SMENP- DC & Phase I & Shenzhen geno- immune medical institute & Gupta and Jain (2010) \\
\hline 13 & Pathogen-specific aAPC & Phase I & Shenzhen geno- immune medical institute & Skirtach et al. (2006) \\
\hline
\end{tabular}

company (Sugentech IVD) has recently developed "SGTi-flex" kit for COVID-19 IgG/IgM detection in suspected samples using the AuNPsbased immuno-chromatographic technique. The kit has visually shown the presence of COVID-19 within the period of not more than $10 \mathrm{~min}$. Hence, it provides the medium for the screening of both symptomatic and asymptomatic patients (Nano the Magazine for Small Science, 2020; South Korean Government, 2020).

AL Tomas et al., has invented two types of "strip lateral flow immunoassays" (LFIA) in 2019 for the diagnosis of pneumocystis pneumonia (P. jirovecii). These tools detect the presence of P. jirceii antibodies with the help of AuNP- recombinant, synthetic antigens (RSA) conjugation reaction. During the demonstrations, both the kits have performed efficiently and were found to have formed redlines in positive samples (Nagatani et al., 2006). Moreover, these Kits are handy and could be conducted at the bedsides, train stations, and airports. Meanwhile, the samples were collected conveniently by fingertip pricking (Storhoff et al.,
1998; Nano the Magazine for Small Science, 2020). However, it was evident that the sample collected via vein does not prioritize those gathered using fingertip pricking, thus affirming the system's reliability and convenience (Nano the Magazine for Small Science, 2020). Nevertheless, such a kind of antibody test can detect SERS-CoV-2 accurately within a few minutes (Tanaka et al., 2006). Z. Zhao et al., Developed carboxyl groupscoated magnetic nanoparticles (pcMNPs)-based viral RNA extraction system for the detection of COVID-19 (Zhao et al., 2020b). Conversely, excellent water disparity is the most promising feature of pcMNPs, making it widely applicable for COVID-19 viral RNA diagnosis in direct RT-PCR (Gan et al., 2020). Henceforth, the extraction procedure will significantly reduce the time consume and specific requirements in current COVID-19 diagnosis, particularly for early clinical diagnosis (Zhao et al., 2020b). And this could resolve the problems associated with RT-PCR based diagnosis technique. Zhenhua 


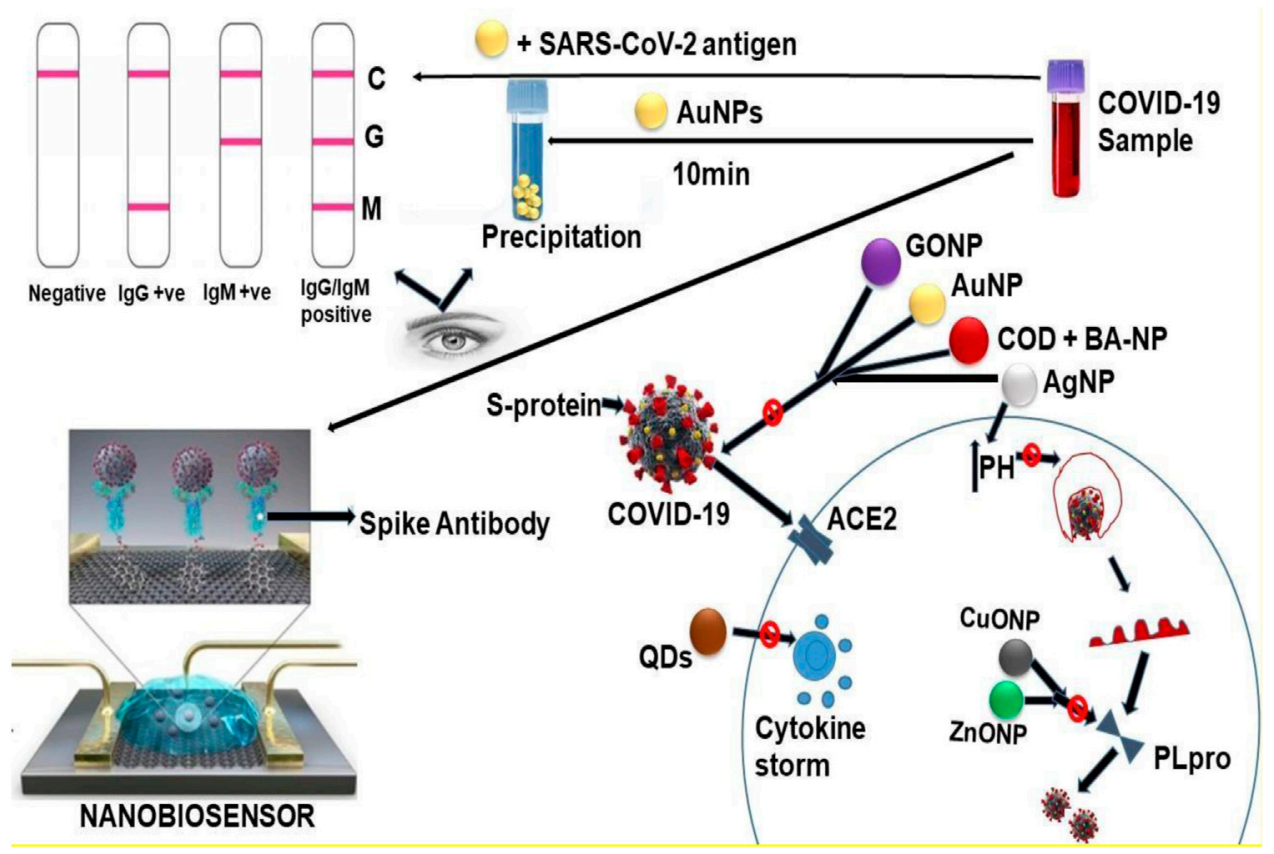

FIGURE 3 | The schematic presentation of the interaction between the components of SARS-CoV-2 and various nanoparticles. GONP = Graphene oxide nanoparticle AuNP = Gold nanoparticle COD-NP = Carbon oxide nanoparticle c BA-NP = Boric acid nanoparticle CuONP = Copper oxide nanoparticle AgNP = Sliver nanoparticle ZnONP = Zinc oxide nanoparticle QDs = Quantum dots.

Chen, et al., has reported the efficiency of "lateral flow immunoassay" (LFIA) in the detection of IgG antibodies produces in human serum in response to COVID-19 infection using "lanthanide-doped polystyrene nanoparticles" (LNPs). The mouse of human anti-IgG antibody incorporated with selfassembled lipid nanoparticles set to produce fluorescence when the SARS-CoV-2 recombinant protein mix with specific IgG on "nitrocellulose membrane" in a short period of $10 \mathrm{~min}$ (Chen et al., 2020). However, this technique could also provide a promising breakthrough for the rapid diagnosis of anti-COVID 19 IgG in the suspected samples. Similarly, Lateral flow test strips designed to detect IgG and IgM in the blood samples have been widely used to detect COVID-19 (Li et al., 2020c). Tian Wen et al., developed a lateral flow immunoassay strip (LFIAs) that selectively detects IgG antibodies against COVID-19's nucleocapsid protein in less than $20 \mathrm{~min}$. The clinical evaluation of this point of care POC assay shows a satisfactory and cost-effective result that could serve as alternative means of confirming SARS-CoV-2 suspected infections (Development of a lateral, 2020).

\section{COVID - 19 TRANSMISSION PREVENTION AND CONTROL USING DIFFERENT NANOPARTICLES}

Nanoparticles are single structure with at least one of their three dimensions that exist as less than $100 \mathrm{~nm}$ in size. Moreover, the chemical compositions of the nanoparticle can be organic or inorganic. Recently, nanoparticles have become increasingly essential and extensively utilized in the biopharmaceutical field due to their unique biocompatibility, biochemical reactivity, conductivity, and reduced toxicity (Vance et al., 2015). Nevertheless, nanoparticles and nanomaterials have a broad scope in healthcare and biopharmaceutical fields. As such, they have been used in the optimization of drug delivery systems, diagnosis, imaging tools, anticancer, antivirals, protective and medical consumables, et al. (Pelaz et al., 2017; Dilnawaz et al., 2018; Sim et al., 2018)

\section{Virus Entry Prevention Using Nanoparticles}

The treatment of specific viral strains is becoming increasingly difficult because of the viruses' frequent evolutions and mutations. On the other hand, nanoparticles can play a vital role in killing and preventing viral entry into the host's cells due to their unique characteristic of interfering with multiple antigens or their surroundings. Nanoparticles such as carbon quantum dots (CQD) and gold nanoparticles (AuNPs) were reported to have been promising tools for preventing viral-cellular entry (Szunerits et al., 2015). The study conducted by Loczechin A. et al., have shown that boronic acid nanoparticles ligands conjugated with carbon quantum dots (CQDs) have interfered with the functions of COVID-19 Spike-proteins and found to have been able to stop its cellular fusion mechanism significantly. Moreover, inhibition of HIV entry using conjugated boronic acid NPs was found to be efficient and successful (Fahmi et al., 2016). Achraf A. et al. demonstrated an experiment by adding nanoparticles to the coronavirus culture medium. Upon 
examination, a considerable reduction in the cell-viral infection and replication rate remarkably reduce. Therefore, nanomaterials can now be employ as a powerful tool to prevent the replication of the viral genome, owing to their nano size of $10 \mathrm{~nm}$, excellent hydrophilicity, and high penetration efficiency (Itani et al., 2020). A characteristic spheroid shape of antiviral nanoparticle has an aspect ratio close to 1 , with a range between $1-50 \mathrm{~nm}$ and an average range of $23 \mathrm{~nm}$ smaller than that of SARS-Cov-2 viral particles. Consequently, nanoparticles have gained a great privilege to contest with the COVID-19 surface spike proteins.

\section{Applications of Nanomaterials}

Brabazon D et al. have extensively investigated the use of nanomaterials in textiles and textiles. Fabrics coated with nanoparticles could be used to enhance the protective effect of Personal Protective Equipment (PPEs), such as lab coats and reusable facemasks. These nanomaterials have been used for UV protection, self-cleaning, fire-resistant clothing, antimicrobials, antivirals (Brabazon et al., 2017) (Figure 2). Therefore, the outbreak of the COVID-19 pandemic raises the need to exploit such nanoparticles due to increased demand for highly protective PPEs and facial masks. As a result, global consumption of Ag nanoparticles increased to 350 tones per year. (Siddiqi et al., 2018). Besides, wearable smart textiles for detecting and sensing biomolecules have been studied, particularly in the healthcare sector (Libertino et al., 2018). However, numerous nanomaterials based coatings are being used currently for various products. Silver, Bismuth, and titanium nanomaterials have been employed for coating surfaces to provide significant protection against microbial invasions (Brabazon et al., 2017). Nowadays, silver base disinfectant is readily available for sanitization purposes of healthcare-related facilities, and they have been found to have inhibited the SARS-Cov-2 contaminated surfaces significantly (Hebalkar et al., 2011). Furthermore, nanomaterials have been used extensively for the protective optimization of air filters in the health setting (Joe et al., 2016; Vaze et al., 2019) and wound dressing materials' production due to their ability to hasten the wound healing process (Mishra et al., 2008; Ali and Ahmed, 2018).

\section{NANOPARTICLES AND MECHANISM OF ANTI- SARS-COV INFECTION}

SARS-CoV related viruses, like all viruses, rely on host cells to reproduce and obtain basic metabolic systems for survival. For example, they use the host cell's cellular machinery to replicate their genetic materials. The investigation of nano systems and their possible interaction mechanisms with viral components may be advantageous for drug delivery enhancement by allowing for surface charge modification of materials (Uskoković, 2020).

\section{Blockage of Viral-Cellular Entry and Attachment}

All viral infections require cellular attachment and entry. Similarly, SARS-CoV 2 infection begins with S-protein binding to the host's ACE2 receptor. The attachment and fusion into the cell are carried out by the two S-protein subunits (S1 and S2) $\mathrm{u}$ sing its $\mathrm{C}$ and $\mathrm{N}$-terminal domains. The $\mathrm{S}_{1}$ subunit is primarily responsible for attaching the virus to the human ACE2 receptor (Hoffmann, 2020). The S2 subunit, on the other hand, mediates the fusion of virus across the cell membrane and endocytosis. The $\mathrm{S}_{2}$ subunit's function is aided by the proteins potential fusion peptide ( $\mathrm{pFP}$ ), transmembrane domain (TM), and heptad repeat $\mathrm{N}$ and $\mathrm{C}$ (HR-N and HR-C) (Ou et al., 2020). As a result, inhibiting this mechanism could be a potential target for antiSARS-CoV2 drug development as well as treatment with repurposed drugs, as in the case of chloroquine (Wang et al., 2020). However, various NPs have the potential to interfere with the viral-cellular interaction as demonstrated by Ting et al. The author reported that cationic carbon dots (CDs) of approximately $1.6 \mathrm{~nm}$ size could interfere with the cellular fusion mechanism of the prototypic 'porcine epidemic diarrhoea virus' SARS-CoV2 (PEDV) (Hu et al., 2020). The effectiveness of CD inhibition is suggested to be due to viral charge neutralization caused by electrostatic interaction between negatively charged PEDV and positively charged cationic CDs. Furthermore, CDs may slow cellular apoptosis by reducing cellular accumulation of reactive oxygen species (ROS). Curcumin-modified AgNPs (cAgNPs) were also tested for their ability to prevent viral-cellular entry more effectively and safely. The cAgNPs have a significant advantage of high surface area due to their nanosized form, allowing them to interfere with the cellular entry process of viral enveloped protein d. (Huang et al., 2019). Similarly, GO in combination with AgNPs has demonstrated a high potential for viral inhibition of cellular entry of both feline COV (FCoV) and enveloped viruses (Yang et al., 2016). Huang et al. also demonstrated that the mechanism of antiviral activity of AuNPs is similar to that of GO-AgNPs (Chen et al., 2016b). Porous silicon NPs (SiNPs), according to Osiminka et al., have an affinity for inhibiting the cellular fusion mechanism of many enveloped viruses, including the nCOV superfamily (Osminkina et al., 2014).

Sekimukai, H. Et al. reported that gold nanoparticles AuNPs act as both an adjuvant and an antigen carrier for immunization. It is believed to be a major adjuvant in the SARS-CoV vaccine that inactivated by ultraviolet radiation. Nasrollahzadeh $\mathrm{M}$ et al. performed preliminary tests on mice by immunizing them with a dose of $0.5 \mu \mathrm{g}$ of spike protein after being infected with the mouse-adapted virus. The adjuvant protein of gold nanoparticles contributes to a strong IgG reaction but does not improve the vaccine's efficacy or reduce eosinophilic infiltration. The result obtained in this study of the gold nanoparticle-adjuvant $S$ protein can lead to a promoted antigen-specific IgG response against SARS-CoV (Nasrollahzadeh et al., 2020; Salleh et al., 2020).

Schlecht S, et al. discovered that AuNPs functionalized with sialic acids could inhibit the cellular entry of the Influenza A virus. The mechanism of inhibition involved the blocking of the viral surface protein (hemagglutinin), which is responsible for the recognition of sialic acid on host cells. According to Stone JW study, functionalized AuNPs with a diameter of $14 \mathrm{~nm}$ are more efficient in blocking the influenza A virus than those with a 


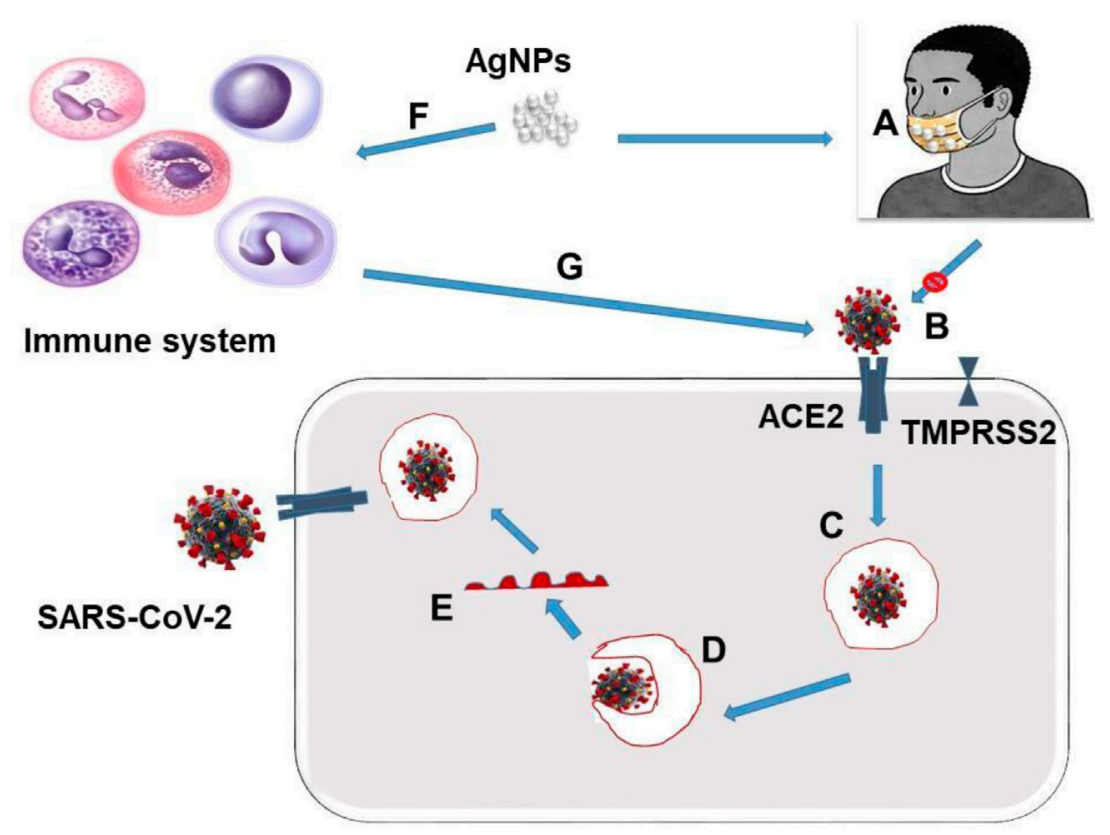

FIGURE 4 | Multiple pathways through with AgNPs mitigate COVID-19 'A' is the reusable facemask coated with Silver nanoparticles AgNPs 'B' Inhibition of COVID-19's Spike protein attachment with ACE2 receptors, preventing the cellular entrance. 'C' Escarpment of COVID-19 from the endosome ' $D$ ' Membrane fusion and uncoating 'E' release of viral genome 'F' Immunostimulation 'G' Strength immune system inhibit cellular entrance of SARS-CoV-2 by preventing the ACE2 receptors and Spike protein attachment.

diameter of $2 \mathrm{~nm}$, which have a less significant outcome (Kim et al., 2020b). Fujimori et al. investigated the antiviral potential of copper iodide nanoparticles (CuINPs) against the 2009 pandemic Influenza A virus. CuINPs can generate reactive oxygen species (ROS), which cause viral degradation and inactivation by acting on essential viral proteins such as neuraminidase and hemagglutinin (Abo-Zeid et al., 2020).

\section{Inhibition of Viral Replication}

The copper surface is very susceptible to modern SARS-CoV-2, which is responsible for the current COVID-19 pandemic. Copper nanoparticles (CuNPs) have antiviral properties that act by blocking papain-like protease-2, a protein that requires replication of severe acute respiratory coronavirus syndrome (SARS-CoV). Oxidized $\mathrm{Cu}$ oxide $(\mathrm{CuO})$ nanoparticles (CuONPs) are commonly used as catalysts to improve the ability of CuONPs to minimize the use of viruses (Sekimukai et al., 2020). On the other hand, Ting Dut et al. reported that turmeric-based cationic carbon dots nanoparticles interact with coronavirus by inhibiting viral proliferation; Curcumin-based cationic carbon dots may inhibit the synthesis of negativestranded RNA and virus budding as well as the aggregation of reactive oxygen species by viruses. The structure of the surface protein in viruses has been altered to prevent viral entry. It may also inhibit viral replication by promoting pro-inflammatory cytokines and interferon-stimulating genes (ISGs) (Du et al., 2018a; Raha et al., 2020). Meanwhile, Jiangong Liang et al. observed that Treatment with Ag2S NCs prohibited the viral budding and negative-strand RNA formation. The formation of
IFN-stimulating genes (ISGs) and the expression of proinflammatory cytokines are positively regulate the inhibition of viral infection and coronavirus proliferation (Lin et al., 2017b). the positive surface charge of carbon-based QDs could be used for sequestering the $\mathrm{S}$ protein of SARS-CoV-2. Besides, cationic surface charges of QDs interact with the virus's negative RNA chain, contributing to reactive oxygen species formation in the COVID - 19. The introduction of desired functional groups with quantum dots may effectively interact with COVID - 19 entry receptors and affects genomic replication (Du et al., 2018b). The schematic presentation of these interactions was presented in Figure 3.

Silver nanoparticles (AgNPs) are used as effective antiviral therapy for SARS-CoV-2 with fewer adverse reactions. The mechanism by which AgNPs interact with COVID-19 is minimal because of the complexity of the COVID-19 structure. Silver nanoparticles interact with COVID-19 in two ways: 1) They bind to the virus's outer layer, thereby inhibiting the attachment of the virus to the receptor cells. 2) They attach to the DNA or RNA virus, thereby inhibiting viral replication within the host cells. Some studies suggested that AgNPs act by binding to the spike glycoprotein virus, thereby inhibiting the virus's attachment to the cells. The release of silver ions could reduce the ambient $\mathrm{pH}$ of the respiratory epithelium, where the COVID-19 virus tends to become more acidic and hostile to the virus (Figure 4; Manivannan and Ponnuchamy, 2020). Because CoVs mutate so quickly, treating human infections remains difficult. In this regard, oczechin, A. et al. developed carbon quantum dots nanoparticles (CQDs-NPs) of approximately $10 \mathrm{~nm}$ size from a citric acid/ 


\section{Binding of $\mathrm{HCoV}$ - 229E virus to host cell}

Target cell membrane

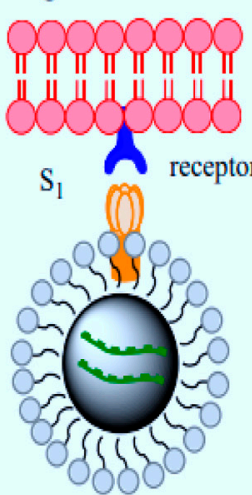

$\mathrm{HCoV}-229 \mathrm{E}$
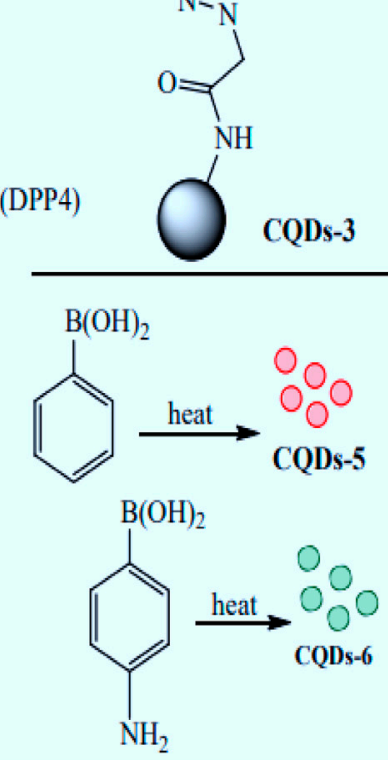

Inhibition of interaction

(a) Target cell membrane

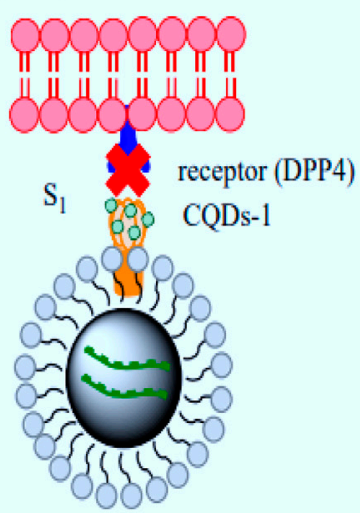

FIGURE 5 | Schematic presentation of the Impact of CQDs, prepared by hydrothermal carbonization, on interaction of HCoV-229E virus and host cells: (a) Inhibition of S protein and host receptor interaction. (b) Inhibition of HCoV-229E-RNA genome replication. Reprinted and manipulated with the permission of references (Łoczechin et al., 2019b).

ethylene diamine precursor and modified them with boric acid. They were discovered to inactivate the $\mathrm{HCoV}-229 \mathrm{E}$ virus in a concentration dependent manner (EC50 of 52- 8-g mL1) (Eoczechin et al., 2019a). Furthermore, the author synthesized CQDs-NPs directly from 4-aminophenylboronic acid with no post-synthetic modifications. The CQDs synthesized using the direct method have the potential for viral inactivation at much lower concentrations, with an EC50 of $5.20 .7 \mathrm{~g}$ mL1 compared to the modified one. The author proposed that the interaction between the functional groups of CQDs and the host's receptor could be a mechanism for both viral inactivation and replication inhibition. (Łoczechin et al., 2019b). As illustrated schematically in Figure 5.

\section{NANOTECHNOLOGY-BASED DRUGS AND VACCINES FOR COVID - 19 TREATMENT}

The absolute genomic similarity between the previous pandemic coronaviruses and SARS-COV2 could greatly help achieve success in vaccines and drug development against the pandemic COVID -19 (Sharma et al., 2019). Nanoparticles are loaded with a range of antigenic moieties using physical or chemical entrapment. Perhaps they have better loading and delivering precise antigen efficiency to the targeted cell than conventional approaches (Pearson et al., 2017). More importantly, nanocarriers' nanosized structure enhances their delivery efficiency, bypasses the biological barrier restrictions, and improves their tissue targeting specificity. Furthermore, they provide flexible administration routes such as oral, intranasal, subcutaneous, and intramuscular routes (Pati et al., 2018). Currently, nanotechnologies have played a significant role in developing four vaccines approved for emergency use against COVID-19 satisfactory completion of phase 2 clinical trials. However, Moderna and Pfizer/BioNTech vaccines were designed by encapsulating the mRNA of SARS-CoV-2 in Lipid Nanoparticles (LNP). Similarly, the Russian Scientist developed the two vaccines received emergency licenses from the Russian Ministry of Health to be used against COVID-19. These vaccines have been reported to achieve higher stability and safety for human use (Table 3 and Table 4; Raha et al., 2020; Du et al., 2018a; Lin et al., 2017b; Du et al., 2018b; Manivannan and Ponnuchamy, 2020; Łoczechin et al., 2019; Sharma et al., 2019; Pearson et al., 2017; Pati et al., 2018; U. S. National Library of Medicine, 2020a; Moderna, 2020a). 
TABLE 5 | Antiviral nanomaterials, applications, and limitations.

\begin{tabular}{|c|c|c|c|c|c|}
\hline $\begin{array}{l}\text { S/ } \\
\text { NO }\end{array}$ & Nanoparticles & $\begin{array}{l}\text { Anti-antiviral } \\
\text { activity }\end{array}$ & Application & Limitations & References \\
\hline 1 & $\begin{array}{l}\text { Hydrogen peroxide. } \\
\mathrm{H}_{2} \mathrm{O}_{2} \text { nanoparticles }\end{array}$ & $\begin{array}{l}\text { Stopping the active of SARS-COV-2 } \\
\text { BY breaking down the structure of the } \\
\text { virus }\end{array}$ & Reduce oxidative stress & $\begin{array}{l}\text { Generate radicals of highly } \\
\text { reactive hydroxyl }\end{array}$ & Ghaffari et al. (2019) \\
\hline 2 & $\begin{array}{l}\text { Ag (silver) } \\
\text { nanoparticles }\end{array}$ & $\begin{array}{l}\text { Cell membrane destruction and DNA } \\
\text { damage }\end{array}$ & Virucidal agents & $\begin{array}{l}\text { The mechanism of inhibition is } \\
\text { not yet understood }\end{array}$ & \\
\hline 3 & $\begin{array}{l}\text { Lipid-based } \\
\text { nanoparticles }\end{array}$ & SiRNA ebola virus & Inhibition of viral replication & Production is costly & Huh and Kwon (2011) \\
\hline 4 & Manganese & Human immunodeficiency virus (HIV) & $\begin{array}{l}\text { Maintain the balance of redox reaction } \\
\text { Increase the rate of mutation of HIV }\end{array}$ & Unrecorded & Antoine et al. (2012) \\
\hline 5 & $\begin{array}{l}\text { Solid lipid } \\
\text { nanoparticles }\end{array}$ & Hepatitis B virus & $\begin{array}{l}\text { Decrease toxicity, with the improved } \\
\text { drug-release profile }\end{array}$ & $\begin{array}{l}\text { Poor loading capacity and high } \\
\text { cost of production }\end{array}$ & $\begin{array}{l}\text { Savrasova et al. } \\
\text { (2011), Ingle et al. } \\
\text { (2014) }\end{array}$ \\
\hline 6 & Gold nanoparticles & $\begin{array}{l}\text { Inhibit and destroy viral particles } \\
\text { directly. Attenuating infectivity of } \\
\text { influenza a virus }\end{array}$ & $\begin{array}{l}\text { Detection of the virus. High specificity } \\
\text { in drug release to target site }\end{array}$ & $\begin{array}{l}\text { Formation of protein binding } \\
\text { complex called "corona" }\end{array}$ & $\begin{array}{l}\text { Trends in IT Value } \\
\text { (2008), Jeyaraj et al. } \\
\text { (2019) }\end{array}$ \\
\hline 7 & $\mathrm{ZnO}-\mathrm{NPs}$ & H1N1 influenza virus inhibition & $\begin{array}{l}\text { Biosensing, antigenic, bio imaging, } \\
\text { and tissue engineering }\end{array}$ & $\begin{array}{l}\text { Biodegradable and } \\
\text { immunogenic "PEGylated with } \\
\text { ZnO-NPs" is alternative }\end{array}$ & $\begin{array}{l}\text { Dehghan et al. (2013), } \\
\text { Sulkowski et al. } \\
(2013)\end{array}$ \\
\hline 8 & Silver (ag) & $\begin{array}{l}\text { Inhibit replication of viruses. E.g. } \\
\text { simple harpies' virus. Hepatitis B }\end{array}$ & $\begin{array}{l}\text { Cancer treatment, biosensor, } \\
\text { biomolecules, and labels of the cell }\end{array}$ & $\begin{array}{l}\text { Induced cytotoxicity in a } \\
\text { mammalian cell }\end{array}$ & Mohajer et al. (2014) \\
\hline 9 & $\mathrm{FeO}$, and CUO & Detection of influenza virus & Antiviral, biosensors & Low detection limit & Heidari et al. (2017) \\
\hline 10 & $\begin{array}{l}\text { Platinum } \\
\text { nanoparticles }\end{array}$ & Detection of influenza virus & Antioxidant, antiviral & In vivo toxicity & $\begin{array}{l}\text { Bimbo et al. (2013), } \\
\text { Pierantoni et al. (2015) }\end{array}$ \\
\hline 11 & $\begin{array}{l}\text { PEGylated IFN and } \\
\text { ribavirin nanoparticles }\end{array}$ & Hepatitis c virus & Liver cirrhosis & Low limit of tolerance & $\begin{array}{l}\text { Faria and Zucolotto } \\
\text { (2019), Lynn et al. } \\
\text { (2015) }\end{array}$ \\
\hline 12 & $\begin{array}{l}\text { Nano spheres } \\
\text { nanoparticles }\end{array}$ & $\begin{array}{l}\text { Hepatitis } B \text {, herpes simplex virus, and } \\
\text { influenza }\end{array}$ & $\begin{array}{l}\text { Inhibition of viral replication, high drug } \\
\text { loading capacity. Neuroprotective } \\
\text { function }\end{array}$ & $\begin{array}{l}\text { High dose requirements } \\
\text { Handling requirements }\end{array}$ & $\begin{array}{l}\text { Dash et al. (2011) } \\
\text { Lee et al. (2018) }\end{array}$ \\
\hline 13 & Silicon nanoparticles & $\begin{array}{l}\text { HIV, Herpes simplex virus, monkey } \\
\text { poxvirus respiratory syncytial virus, } \\
\text { and hepatitis B virus }\end{array}$ & $\begin{array}{l}\text { High delivery of antiviral to infected } \\
\text { cells } \\
\text { Immunosensors } \\
\text { Bioanalytical research }\end{array}$ & Cytotoxicity & $\begin{array}{l}\text { Liu et al. (2015), Cai } \\
\text { et al. (2017) }\end{array}$ \\
\hline 14 & Chitosan & $\begin{array}{l}\text { HIN2 influenza } \\
\text { H1N1, H3N2, H5N1 influenza }\end{array}$ & $\begin{array}{l}\text { Micro molecules delivery. Include } \\
\text { vaccines and protein across the nasal } \\
\text { mucosa and oral system }\end{array}$ & Low aqueous barrier properties & Dash et al. (2011) \\
\hline
\end{tabular}

\section{Benefit and Challenges of Using Nanomedicines in Mitigating COVID - 19}

Generally, nanomedicine changes the paradigm of healthcare delivery owing to its potential therapeutic effectiveness. Moreover, they have a wide range of applications in therapeutics, diagnosis, and overall healthcare delivery (Singh et al., 2018). The developmental aspects of nanotechnology and its clinical applications are understudying. Perhaps, there are enormous challenges that need to be addressed in exploring their clinical significance. Therefore, specialists' hands need to be on deck to optimize their full potentiality in all aspects of medical space (McNamara and Tofail, 2017). We summarised the clinical benefits and challenges associated with the use of nanomaterials were for the management of viral infections in Table 5.

\section{CONCLUSION}

This study suggested that nanotechnology could serve as a promising alternative to reduce the spread of COVID-19 across multiple techniques. Besides, it greatly optimizes viral diagnosis by making it possible to detect viral genome presence in a minute sample quantity within a short period. It is also possible to diagnose COVID-19 in asymptomatic patients. It can, therefore, reduce the chances of viral transmission. Several nanoparticles and nanomaterials have also been found to possess the unique properties of viral inactivation, block its entrance mechanism, and inhibit several vital proteins responsible for viral attachment and intercellular replication. However, Nanotechnology has potentially accelerated the process of novel drugs and vaccine designation and delivery against COVID-19.

\section{AUTHOR CONTRIBUTIONS}

AM: COVID - 19 transmission prevention and control using different nanoparticles. MA: Specific applications of nanosensors for the detection of COVID - 19 3. NA: Rapid testing of COVID 19 using other NPs. MM (7th author): Application of nanoparticles in vaccines and drug delivery against COVID 19. AY: How a COVID - 19 infects cells. MY: Challenges in the phase of nanomedicines use against COVID-19 and their prospective solutions. SS: Latest updates on the status of nanotechnology-based drugs and vaccines in clinical trials 
against COVID -19. MM (3rd author): Nanoradiations: either a diagnostic test or curable means or against COVID- -19 virus. IS: Drawing of figures and manuscript writing. YBD: Antiviral nanoparticles/nanomaterials. MI: Approving the final version of the manuscript.

\section{REFERENCES}

Abo-Zeid, Yasmin., Ismail, N. S. M., McLean, G. R., and Hamdy, N. M. (2020). A Molecular Docking Study Repurposes FDA Approved Iron Oxide Nanoparticles to Treat and Control COVID-19 Infection. Eur. J. Pharm. Sci. 153,105465

Adesina, S. K., and Akala, E. O. (2015). Nanotechnology Approaches for the Delivery of Exogenous siRNA for HIV Therapy. Mol. Pharmaceutics 12, 4175-4187. doi:10.1021/acs.molpharmaceut.5b00335

Ahmed, M. K., Afifi, M., and Uskoković, V. (2020). Protecting Healthcare Workers during COVID-19 Pandemic with Nanotechnology: A Protocol for a New Device from Egypt. J. Infect. Public Health 13, 1243. doi:10.1016/ j.jiph.2020.07.015

Ahmed, S. F., Quadeer, A. A., and McKay, M. R. (2020). Preliminary Identification of Potential Vaccine Targets for the COVID-19 Coronavirus (SARS-CoV-2) Based on SARS-CoV Immunological Studies. Viruses 12, 254. doi:10.3390/ v12030254

Aldewachi, H., Chalati, T., Woodroofe, M. N., Bricklebank, N., Sharrack, B., and Gardiner, P. (2018). Gold Nanoparticle-Based Colorimetric Biosensors. Nanoscale 10, 18. doi:10.1039/c7nr06367a

Ali, A., and Ahmed, S. (2018). A Review on Chitosan and its Nanocomposites in Drug Delivery. Int. J. Biol. Macromol 109, 273. doi:10.1016/ j.ijbiomac.2017.12.078

Amanat, F., and Krammer, F. (2020). SARS-CoV-2 Vaccines: Status Report. Immunity 5221, 5831-5899. doi:10.1016/j.immuni.2020.03.007IksalM

Aminu Shehu, I., and Mukhtar, A. (2020). Intervention of Novel Nanotechnology in Fight against Covid 19. Sci. Posters, 18184. doi:10.14293/S2199-1006.1.SOR.PPQMYJ1.V1

American Chemical Society (2020) Proof-of-Concept for Faster COVID-19 Test: News: Chemistry Views. Available at: https://www.chemistryviews.org/details/ news/11234958/Proof-of-Concept_for_Faster_COVID-19_Test.html (Accessed October 1, 2020).

Among, H., Symptomatic, I. W., Results, S., Available, N. R., States, U., States, U., et al. (2020). ClinicalTrials.gov Search Results 07/18/2020. 18-20.

Antoine, T. E., Mishra, Y. K., Trigilio, J., Tiwari, V., Adelung, R., and Shukla, D. (2012). Prophylactic, Therapeutic and Neutralizing Effects of Zinc Oxide Tetrapod Structures against Herpes Simplex Virus Type-2 Infection. Antivir. Res 96, 363. doi:10.1016/j.antiviral.2012.09.020

AuthorAnonymous (2017). Emerging Respiratory Disease-Coronaviruses. Disease-a-Month. 63, 256-262. doi:10.1016/j.disamonth.2017.03.019

Bahl, P., Doolan, C., de Silva, C., Chughtai, A. A., Bourouiba, L., and MacIntyre, C. R. (2020). Airborne or Droplet Precautions for Health Workers Treating Coronavirus Disease 2019? J. Infect. Dis., jiaa189. doi:10.1093/infdis/jiaa189

Baig, A. M., Khaleeq, A., Ali, U., and Syeda, H. (2020). Evidence of the COVID-19 Virus Targeting the CNS: Tissue Distribution, Host-Virus Interaction, and Proposed Neurotropic Mechanisms. ACS Chem. Neurosci. 11 (7), 995-998. doi:10.1021/acschemneuro.0c00122

Balfour, Hannah.European Pharmaceutical Review (2020). Simple but Effective: an Experimental Nanoparticle COVID-19 Test.https://scihub.tw/https://www. europeanpharmaceuticalreview.com/news/120545/simple-buteffective-anexperimental-nanoparticle-covid-19-test/

Bimbo, L. M., Denisova, O. V., Mäkilä, E., Kaasalainen, M., De Brabander, J. K., Hirvonen, J., et al. (2013). Inhibition of Influenza A Virus Infection In Vitro by Saliphenylhalamide- Loaded Porous Silicon Nanoparticles. ACS Nano 7, 6884. doi:10.1021/nn402062f

Biomedical and Pharmaceutical Sciences (2020). Global Epidemic of Coronavirus - Covid-19: What Can We Do to. Eur. J. Biomed. Pharm. Sci. 7, 432-438

\section{ACKNOWLEDGMENTS}

Authors acknowledged the contributions given by Amita Verma, School of Health and Allied Sciences, SHUATS University, Allahabad, UP, India.

Böhm, A., Trosien, S., Avrutina, O., Kolmar, H., and Biesalski, M. (2018). Covalent Attachment of Enzymes to Paper Fibers for Paper-Based Analytical Devices. Front. Chem. 6, 214. doi:10.3389/fchem.2018.00214

Borrego, B., Lorenzo, G., Mota-Morales, J. D., Almanza-Reyes, H., Mateos, F., López-Gil, E., et al. (2016). Potential Application of Silver Nanoparticles to Control the Infectivity of Rift Valley Fever Virus In Vitro and In Vivo. Nanomedicine: Nanotechnology, Biol. Med. 12, 1185-1192. doi:10.1016/ j.nano.2016.01.021

Brabazon, D., Pellicer, E., Zivic, F., Sort, J., Baró, M. D., Grujovic, N., et al. (2017). Commercialization of Nanotechnologies-A Case Study Approach. doi:10.1007/ 9783-319-56979-6

Burdușel, A. C., Gherasim, O., Grumezescu, A. M., Mogoantă, L., Ficai, A., and Andronescu, E. (2018). Biomedical Applications of Silver Nanoparticles: An Up-To-Date Overview. Nanomaterials (Basel) 8, 1-24. doi:10.3390/ nano8090681

Cai, M., Wang, C., Li, Y., Gu, H., Sun, S., Duan, Y., et al. (2017). Virus-like Particle Vaccine by Intranasal Vaccination Elicits Protective Immunity against Respiratory Syncytial Viral Infection in Mice. Acta Biochim. Biophys. Sin (Shanghai) 49, 74. doi:10.1093/abbs/gmw118

Campuzano, S., Yáñez-Sedeño, P., and Pingarrón, J. M. (2019). Carbon Dots and Graphene Quantum Dots in Electrochemical Biosensing. Nanomaterials 9, 634. doi:10.3390/nano9040634

Cao, Y. C., Deng, Q. X., and Dai, S. X. (2020). Remdesivir for Severe Acute Respiratory Syndrome Coronavirus 2 Causing COVID-19: An Evaluation of the Evidence. Trav. Med Infect Dis 35, 101647. doi:10.1016/ j.tmaid.2020.101647xinxue

Chan, J. F. W., Yuan, S., Kok, K. H., To, K. K. W., Chu, H., Yang, J., et al. (2020). A Familial Cluster of Pneumonia Associated with the 2019 Novel Coronavirus Indicating Person-To-Person Transmission: a Study of a Family Cluster. Lancet 395, 514. doi:10.1016/S0140-6736(20)30154-9

Chauhan, G., Madou, M. J., Kalra, S., Chopra, V., Ghosh, D., Martinez-Chapa, S. O., et al. (2020). Nanotechnology for COVID-19: Therapeutics and Vaccine ResearchThe COVID-19 Vaccine Development Landscape. ACS Nanonat Rev. Drug Discov. 19, 305-306. doi:10.1021/acsnano.0c04006Thanh10.1038/ d41573-020-00073-5

Chen, M., and Yin, M. (2014). Design and Development of Fluorescent Nanostructures for Bioimaging. Prog. Polym. Sci. 39, 365. doi:10.1016/ j.progpolymsci.2013.11.001

Chen, N., Zheng, Y., Yin, J., Li, X., and Zheng, C. (2013). Inhibitory Effects of Silver Nanoparticles against Adenovirus Type 3 In Vitro. J. Virol. Methods 193, 470-477. doi:10.1016/j.jviromet.2013.07.020

Chen, Y.-N., Hsueh, Y.-H., Hsieh, C.-T., Tzou, D.-Y., and Chang, P.-L. (2016). Antiviral Activity of Graphene-Silver Nanocomposites against Non-enveloped and Enveloped Viruses. Ijerph 13, 430. doi:10.3390/ijerph13040430

Chen, Z., Zhang, Z., Zhai, X., Li, Y., Lin, L., Zhao, H., et al. (2020). Rapid and Sensitive Detection of Anti-SARS-CoV - 2 IgG, Using Lanthanide-Doped Nanoparticles-Based Lateral Flow Immunoassay. Anal. Chem. 92 (10), 7226-7231. doi:10.1021/acs.analchem.0c00784

Choi, J. R. (2020). Development of Point-of-Care Biosensors for COVID-19. Front. Chem. 8, 8. doi:10.3389/fchem.2020.00517

Choi, J. W., Kim, Y. J., Lee, J. M., Choi, J.-H., Choi, J.-W., and Chung, B. G. (2020). Droplet-based Synthesis of Homogeneous Gold Nanoparticles for Enhancing HRP-Based ELISA Signals. Biochip J. 14, 298. doi:10.1007/s13206-020-4307-z

Choi, J., Yong, K., Choi, J., and Cowie, A. (2019). Emerging point-of-care Technologies for Food Safety Analysis. Sensors 19 (4), 817. doi:10.3390/ s19040817

Cooper, D. R., D’Anjou, B., Ghattamaneni, N., Harack, B., Hilke, M., Horth, A., et al. (2012). Experimental Review of Graphene. ISRN Condensed Matter Phys. 2012, 1-56. doi:10.5402/2012/501686 
Cui, H., Jiang, J., Gu, W., Sun, C., Wu, D., Yang, T., et al. (2010). Photocatalytic Inactivation Efficiency of Anatase Nano-TiO2 Sol on the H9N2 Avian Influenza Virus. Photochem. Photobiol. 86, 1135-1139. doi:10.1111/j.17511097.2010.00763.x

Das, P., Das, M., Chinnadayyala, S. R., Singha, I. M., and Goswami, P. (2016). Recent Advances on Developing 3rd Generation Enzyme Electrode for Biosensor Applications. Biosens. Bioelectron. 79, 386-397. doi:10.1016/ j.bios.2015.12.055

Dash, M., Chiellini, F., Ottenbrite, R. M., and Chiellini, E. (2011). Chitosan - A Versatile Semi-synthetic Polymer in Biomedical Applications. Prog. Polym. Sci. 36, 981. doi:10.1016/j.progpolymsci.2011.02.001

Dehghan, S., Kheiri, M. T., Tabatabaiean, M., Darzi, S., and Tafaghodi, M. (2013). Dry-powder Form of Chitosan Nanospheres Containing Influenza Virus and Adjuvants for Nasal Immunization. Arch. Pharm. Res. 36, 981. doi:10.1007/ s12272-013-0043-4

Devaux, C. A., Rolain, J.-M., and Raoult, D. (2020). ACE2 Receptor Polymorphism: Susceptibility to SARS-CoV-2, Hypertension, Multi-Organ Failure, and COVID-19 Disease Outcome. J. Microbiol. Immunol. Infect. 53 (3), 425-435. doi:10.1016/j.jmii.2020.04.015

Dhama, K., Sharun, K., Tiwari, R., Dadar, M., Malik, Y. S., Singh, K. P., et al. (2020). COVID-19, an Emerging Coronavirus Infection: Advances and Prospects in Designing and Developing Vaccines, Immunotherapeutics, and Therapeutics. Hum. Vaccin. Immunother. 16 (6), 1232-1238. doi:10.1080/ 21645515.2020.1735227

Dicker, D., Nguyen, G., Abate, D., Abate, K. H., Abay, S. M., Abbafati, C., et al. (2018). Global, Regional, and National Age-sex-specific Mortality and Life Expectancy, 1950-2017: A Systematic Analysis for the Global Burden of Disease Study 2017. Lancet 392, 1684-1735. doi:10.1016/S0140-6736(18) 31891-9

Dilnawaz, F., Acharya, S., and Sahoo, S. K. (2018). Recent Trends of Nanomedicinal Approaches in Clinics. Int. J. Pharm. 538, 263. doi:10.1016/ j.ijpharm.2018.01.016

Du, T., Dong, N., Fang, L., Lu, J., Jing, Bi., Xiao, Shaobo., et al. (2018a). Multi-Site Inhibitors for Enteric Coronavirus: Antiviral Cationic Carbon Dots Based on Curcumin. https://pubs.acs.org/doi/suppl/101021/acsanm8b00779/suppl_file/ an8b00779_si_001.pdf

Du, Ting., Liang, Jiangong., Dong, Nan., Lu, J., Fu, Y., Fang, Liurong., et al. (2018b). Supporting Information of Glutathione-Capped Ag2S Nanoclusters Inhibit Coronavirus Proliferation through Blockage of Viral RNA Synthesis and Budding. https://pubs.acs.org/doi/suppl/101021/acsami7b13811/suppl_file/ am7b13811_si_001.pdf

Elfiky, A. A. (2020). Anti-HCV, Nucleotide Inhibitors, Repurposing against COVID-19. Life Sci. 248, 117477. doi:10.1016/j.lfs.2020.117477

Fahmi, M. Z., Sukmayani, W., Khairunisa, S. Q., Witaningrum, A. M., Indriati, D. W., Matondang, M. Q. Y., et al. (2016). Design of Boronic Acid-Attributed Carbon Dots on Inhibits HIV-1 Entry. RSC Adv. 6, 92996. doi:10.1039/ c6ra21062g

Faria, H. A. M., and Zucolotto, V. (2019). Label-free Electrochemical DNA Biosensor for Zika Virus Detection Sequences. Biosens. Bioelectron. 131, 149-155. doi:10.1016/j.bios.2019.02.018

Gan, Y., Du, L., Damola, F. O., Huang, J., Xiao, G., and Lyu, X. (2020). Sample Pooling as a Strategy of SARS-COV-2 Nucleic Acid Screening Increases the FalseNegative Rate. medRxiv. doi:10.1101/2020.05.18.20106138

Ge, Z.-y., Yang, L.-m., Xia, J.-j., Fu, X.-h., and Zhang, Y.-z. (2020). Possible Aerosol Transmission of COVID-19 and Special Precautions in Dentistry. J. Zhejiang Univ. Sci. B 21, 361-368. doi:10.1631/jzus.B2010010

Geim, A. K., and Novoselov, K. S. (2007). The Rise of Graphene. Nat. Mater 6, 183-191. doi:10.1038/nmat1849

Ghaffari, H., Tavakoli, A., Moradi, A., Tabarraei, A., Bokharaei-Salim, F., Zahmatkeshan, M., et al. (2019). Inhibition of H1N1 Influenza Virus Infection by Zinc Oxide Nanoparticles: Another Emerging Application of Nanomedicine. J. Biomed. Sci. 26, 70. doi:10.1186/s12929-019-0563-4

Govorov, A. O., and Richardson, H. H. (2007). Generating Heat with Metal Nanoparticles. Nano Today 2, 30-38. doi:10.1016/S1748-0132(07) 70017-8

Gupta, U., and Jain, N. K. (2010). Non-polymeric Nanocarriers in HIV/AIDS Drug Delivery and Targeting. Adv. Drug Deliv. Rev. 62, 478. doi:10.1016/ j.addr.2009.11.018
Hebalkar, N. Y., Acharya, S., and Rao, T. N. (2011). Preparation of Bi-functional Silica Particles for Antibacterial and Self Cleaning Surfaces. J. Colloid Interf. Sci 64, 24. doi:10.1016/j.jcis.2011.07.087

Heidari, H., Ahangarpour, A., Junghani, M., Absari, R., Khoogar, M., and Ghaedi, E. (2017). Effects of Hydroalcoholic Extract of Rhus Coriaria Seed on Glucose and Insulin Related Biomarkers, Lipid Profile, and Hepatic Enzymes in Nicotinamide-Streptozotocin-Induced Type II Diabetic Male Mice. Res. Pharm. Sci. 12, 416. doi:10.4103/1735-5362.213987

Hoffmann, M., Kleine-Weber, H., Schroeder, S., Kruger, N., Herrler, T., Erichsen, S., et al. (2020). SARS-CoV-2 Cell Entry Depends on ACE2 and TMPRSS2 and Is Blocked by a Clinically Proven Protease Inhibitor. Cell 181: 271-280.

History and Culture (2020). June Almeida Discovered Coronaviruses Decades Ago-But Got Little Recognition. Available at: https:/www.nationalgeographic. com/history/2020/04/june-almeida-discoveredcoronaviruses-decades-ago-littlerecognition/ (Accessed October 7, 2020)

Hsiao, C.-Y., Lin, C.-H., Hung, C.-H., Su, C.-J., Lo, Y.-R., Lee, C.-C., et al. (2009). Novel Poly-Silicon Nanowire Field Effect Transistor for Biosensing Application. Biosens. Bioelectron. 24, 1223-1229. doi:10.1016/ j.bios.2008.07.032

Hu, J., Choi, J. R., Wang, S., Gong, Y., Feng, S., Pingguan-Murphy, B., et al. (2017). Multiple Test Zones for Improved Detection Performance in Lateral Flow Assays. Sensors Actuators B: Chem. 243, 484. doi:10.1016/j.snb.2016.12.008

$\mathrm{Hu}, \mathrm{T}$. Y., Frieman, M., and Wolfram, J. (2020). Insights from Nanomedicine into Chloroquine Efficacy against Covid-19. Nat. Nanotechnol. (2020), 15: 247-249.

Hua, S., and Wu, S. Y. (2018). Editorial: Advances and Challenges in Nanomedicine. Front. Pharmacol. 9, 1-3. doi:10.3389/fphar.2018.01397

Huang, B., Ling, R., Cheng, Y., Wen, J., Dai, Y., Huang, W., et al. (2020). Characteristics and Therapeutic Options of the Coronavirus Disease 2019. Mol. Ther. Methods Clin. Dev. 18, 367. doi:10.1016/j.omtm.2020.06.013

Huang, C., Wen, T., Shi, F. J., Zeng, X. Y., and Jiao, Y. J. (2020). Rapid Detection of IgM Antibodies against the SARS-CoV-2 Virus via Colloidal Gold Nanoparticle-Based Lateral-Flow Assay. ACS Omega 5, 12550-12556. doi:10.1021/acsomega.0c01554

Huang, X., Li, M., Xu, Y., Zhang, J., Meng, X., An, X., et al. (2019). Novel Gold Nanorod-Based HR1 Peptide Inhibitor for Middle East Respiratory Syndrome Coronavirus. ACS Appl. Mater. Inter. 11:19799-19807.

Huh, A. J., and Kwon, Y. J. (2011). "Nanoantibiotics": A New Paradigm for Treating Infectious Diseases Using Nanomaterials in the Antibiotics Resistant Era. J. Control. Release 156, 128. doi:10.1016/j.jconrel.2011.07.002

Hussain, K., Dewan, V., Ali, T., and Al Shakarchi, J. (2020). The Impact of the COVID-19 Pandemic on the Provision of Surgical Care. J. Surg. Case Rep. 2020, 2020. doi:10.1093/jscr/rjaa087

Ingle, A. P., Duran, N., and Rai, M. (2014). Bioactivity, Mechanism of Action, and Cytotoxicity of Copperbased Nanoparticles: A Review. Appl. Microbiol. Biotechnol. 98, 1001. doi:10.1007/s00253013-5422-8

Ishida, T. (2018). Antiviral Activities of $\mathrm{Cu} 2+$ Ions in Viral Prevention, Replication, RNA Degradation, and for Antiviral Efficacies of Lytic Virus, ROS-Mediated Virus, Copper Chelation. World Sci. 99, 148-160.

Itani, R., Tobaiqy, M., and Al Faraj, A. (2020). Optimizing Use of Theranostic Nanoparticles as a Lifesaving Strategy for Treating COVID-19 Patients. Theranostics 10, 5932-5942. doi:10.7150/thno.46691

Jackman, J. A., Lee, J., and Cho, N.-J. (2016). Nanomedicine for Infectious Disease Applications: Innovation towards Broad-Spectrum Treatment of Viral Infections. Small 12, 1133-1139. doi:10.1002/smll.201500854

Jayaweera, M., Perera, H., Gunawardana, B., and Manatunge, J. (2020). Transmission of COVID-19 Virus by Droplets and Aerosols: A Critical Review on the Unresolved Dichotomy. Environ. Res. 188, 109819. doi:10.1016/j.envres.2020.109819

Jeyaraj, M., Gurunathan, S., Qasim, M., Kang, M. H., and Kim, J. H. (2019). A Comprehensive Review on the Synthesis, Characterization, and Biomedical Application of Platinum Nanoparticles. Nanomaterials 9, 1719. doi:10.3390/ nano9121719

Ji, H., Yang, Z., Jiang, W., Geng, C., Gong, M., Xiao, H., et al. (2008). Antiviral Activity of Nano Carbon Fullerene Lipidosome against Influenza Virus In Vitro. J. Huazhong Univ. Sci. Technol. [Med. Sci. 28, 243-246. doi:10.1007/ s11596-008-0303-6

Jin, Y. H., Cai, L., Cheng, Z. S., Cheng, H., Deng, T., Fan, Y. P., et al. (2020). A Rapid Advice Guideline for the Diagnosis and Treatment of 2019 Novel Coronavirus 
(2019-nCoV) Infected Pneumonia (Standard Version). Med. J. Chin. People's Lib Army 45, 1-20. doi:10.11855/j.issn.0577-7402.2020.01.01

Jin, Y., Wang, M., Zuo, Z., Fan, C., Ye, F., Cai, Z., et al. (2020). Diagnostic Value and Dynamic Variance of Serum Antibody in Coronavirus Disease 2019. Int. J. Infect. Dis. 94, 49-52. doi:10.1016/j.ijid.2020.03.065

Joe, Y. H., Park, D. H., and Hwang, J. (2016). Evaluation of Ag Nanoparticle Coated Air Filter against Aerosolized Virus: Antiviral Efficiency with Dust Loading. J. Hazard. Mater. 301, 547. doi:10.1016/j.jhazmat.2015.09.017

Joshi, R. K., and Bhansali, S. (2008). Nanosensor Technology. J. Nanomater. 2008, 1. doi:10.1155/2008/840390

Ketkar, H., Yang, L., Wormser, G. P., and Wang, P. (2019). Lack of Efficacy of Ivermectin for Prevention of a Lethal Zika Virus Infection in a Murine System. Diagn. Microbiol. Infect. Dis. 95, 38-40. doi:10.1016/ j.diagmicrobio.2019.03.012

Kim, E., Erdos, G., Huang, S., Kenniston, T. W., Balmert, S. C., Carey, C. D., et al. (2020). Microneedle Array Delivered Recombinant Coronavirus Vaccines: Immunogenicity and Rapid Translational Development. EBioMedicine 55, 102743. doi:10.1016/j.ebiom.2020.102743

Kim, Jinyoung., Yeom, Minjoo., Lee, Taeksu., Kim, Hyun-Ouk., Na, Woonsung., Kang, Aram., et al. (2020). Porous Gold Nanoparticles for Attenuating Infectivity of Influenza A Virus. J. Nanobiotechnology 18, 1-11.

Lagier, J. C., Colson, P., Tissot Dupont, H., Salomon, J., Doudier, B., Aubry, C., et al. (2020). Testing the Repatriated for SARS-Cov2: Should Laboratorybased Quarantine Replace Traditional Quarantine? Trav. Med Infect Dis 34, 101624. doi:10.1016/j.tmaid.2020.101624

Lara, H. H., Garza-Treviño, E. N., Ixtepan-Turrent, L., and Singh, D. K. (2011). Silver Nanoparticles Are Broad-Spectrum Bactericidal and Virucidal Compounds. J. Nanobiotechnology 9, 30. doi:10.1186/1477-3155-9-30

Lara, H. H., Ixtepan-Turrent, L., Garza-Treviño, E. N., and Rodriguez-Padilla, C. (2010). PVP-coated Silver Nanoparticles Block the Transmission of Cell-free and Cell-Associated HIV-1 in Human Cervical Culture. J. Nanobiotechnology 8 , 15. doi:10.1186/1477-3155-8-15

Layqah, L. A., and Eissa, S. (2019). An Electrochemical Immunosensor for the corona Virus Associated with the Middle East Respiratory Syndrome Using an Array of Gold Nanoparticle-Modified Carbon Electrodes. Microchim Acta 186, 224. doi:10.1007/s00604-019-3345-5

Lee, Y. T., Ko, E. J., Lee, Y., Kim, K. H., Kim, M. C., Lee, Y. N., et al. (2018). Intranasal vaccination with M2e $5 \mathrm{x}$ virus-like particles induces humoral and cellular immune responses conferring cross-protection against heterosubtypic influenza viruses. PLoS One 13, e0190868. doi:10.1371/ journal.pone. 0190868

Lei, Y.-M., Xiao, M.-M., Li, Y.-T., Xu, L., Zhang, H., Zhang, Z.-Y., et al. (2017). Detection of Heart Failure-Related Biomarker in Whole Blood with Graphene Field Effect Transistor Biosensor. Biosens. Bioelectron. 91, 1-7. doi:10.1016/ j.bios.2016.12.018

Li, D., Wang, D., Dong, J., Wang, N., Huang, H., Xu, H., et al. (2020). False-negative Results of Real-Time Reverse-Transcriptase Polymerase Chain Reaction for Severe Acute Respiratory Syndrome Coronavirus 2: Role of Deep-LearningBased Ct Diagnosis and Insights from Two Cases. Korean J. Radiol. 21, 505-508. doi:10.3348/kjr.2020.0146

Li, L., Fernández-Cruz, M. L., Connolly, M., Conde, E., Fernández, M., Schuster, M., et al. (2015). The Potentiation Effect Makes the Difference: Non-toxic Concentrations of $\mathrm{ZnO}$ Nanoparticles Enhance $\mathrm{Cu}$ Nanoparticle Toxicity In Vitro. Sci. Total Environ. 505, 253-260. doi:10.1016/j.scitotenv.2014.10.020

Li, Q., Guan, X., Wu, P., Wang, X., Zhou, L., Tong, Y., et al. (2020). Early Transmission Dynamics in Wuhan, China, of Novel CoronavirusInfected Pneumonia. N. Engl. J. Med. 382, 1199-1207. doi:10.1056/ NEJMoa2001316

Li, Z., Yi, Y., Luo, X., Xiong, N., Liu, Y., Li, S., et al. (2020). Development and Clinical Application of a Rapid IgM-IgG Combined Antibody Test for SARSCoV-2 Infection Diagnosis. J. Med. Virol. 92 (9), 1518-1524. doi:10.1002/ jmv. 25727

Libertino, S., Plutino, M. R., and Rosace, G. (2018). Design and Development of Wearable Sensing Nanomaterials for Smart Textiles. AIP Conf. Proc. 1990. doi:10.1063/1.5047770

Lin, Y., Zhang, H., Song, W., Si, S., Han, Y., and Jiang, J. (2019). Identification and Characterization of Zika Virus NS5 RNA-dependent RNA Polymerase
Inhibitors. Int. J. Antimicrob. Agents 54, 502. doi:10.1016/ j.ijantimicag.2019.07.010

Lin, Z., Li, Y., Guo, M., Xiao, M., Wang, C., Zhao, M., et al. (2017). Inhibition of H1N1 Influenza Virus by Selenium Nanoparticles Loaded with Zanamivir through P38 and Jnk Signaling Pathways. RSC Adv. 7.35290-35296.

Lin, Z., Li, Y., Guo, M., Xu, T., Wang, C., Zhao, M., et al. (2017). The Inhibition of H1N1 Influenza Virus-Induced Apoptosis by Silver Nanoparticles Functionalized with Zanamivir. RSC Adv. 7, 742-750. doi:10.1039/c6ra25010f

Liu, J., Liao, X., Qian, S., Yuan, J., Wang, F., Liu, Y., et al. (2020). Community Transmission of Severe Acute Respiratory Syndrome Coronavirus 2. China: Shenzhen. doi:10.3201/eid2606.200239

Liu, J., Geng, Z., Fan, Z., Liu, J., and Chen, H. (2019). Point-of-care Testing Based on Smartphone: The Current State-Of-The-Art (2017-2018). Biosens. Bioelectron. 132, 17. doi:10.1016/j.bios.2019.01.068

Liu, Q., Zheng, X., Zhang, C., Shao, X., Zhang, X., Zhang, Q., et al. (2015). Conjugating Influenza a (H1N1) Antigen to N-Trimethylaminoethylmethacrylate Chitosan Nanoparticles Improves the Immunogenicity of the Antigen after Nasal Administration. J. Med. Virol. 87, 1807. doi: $10.1002 / j m v .24253$

Loeb, S., Li, C., and Kim, J.-H. (2018). Solar Photothermal Disinfection Using Broadband-Light Absorbing Gold Nanoparticles and Carbon Black. Environ. Sci. Technol. 52, 205-213. doi:10.1021/acs.est.7b04442

Lou, S., Ye, J. Y., Li, K. Q., and Wu, A. (2012). A Gold Nanoparticle-Based Immunochromatographic Assay: The Influence of Nanoparticulate Size. Analyst 137 (5), 1174-1181. doi:10.1039/c2an15844b

Lynn, G. M., Laga, R., Darrah, P. A., Ishizuka, A. S., Balaci, A. J., Dulcey, A. E., et al. (2015). In Vivo characterization of the Physicochemical Properties of PolymerLinked TLR Agonists that Enhance Vaccine Immunogenicity. Nat. Biotechnol. 33, 1201. doi:10.1038/nbt.3371

Majumdar, A., Malviya, N., and Alok, S. (2020). An Overview on Covid-19 Outbreak: Epidemic to Pandemic. Int. J. Pharm. Sci. Res. 11, 1958-1968. doi:10.13040/IJPSR.09758232.11(5).1958-68

Manivannan, S., and Ponnuchamy, K. (2020). Quantum Dots as a Promising Agent to Combat COVID-9. Appl. Organomet. Chem., 17-22. doi:10.1002/aoc.5887

McNamara, K., and Tofail, S. A. M. (2017). Nanoparticles in Biomedical Applications. Adv. Phys. 2, 54. doi:10.1080/23746149.2016.1254570

Medicine USNL of (2020). Safety and Immunogenicity Study of 2019-nCoV Vaccine ( mRNA-1273) for Prophylaxis SARS CoV-2 Infection (COVID-19). US Natl. Libr. Med.

Mishra, M., Kumar, H., and Tripathi, K. (2008). Diabetic Delayed Wound Healing and the Role of Silver Nanoparticles. Dig. J. Nanomater. Bios 3,49 .

Mizuta, H., Sun, J., Schmidt, M. E., and Muruganathan, M. (2016). (Invited) Highly Functional Graphene Nano-Electromechanical (GNEM) Devices for Advanced Switch and Sensor Applications. ECS Trans. 75, 3. doi:10.1149/ 07513.0003ecst

Moderna. Moderna's Work on a Potential Vaccine against COVID-19. 153. Www. Biorxiv.Org.

Moderna (2020). Moderna Announces Positive Interim Phase 1 Data for its mRNA Vaccine (mRNA-1273) against Novel Coronavirus. 2-4.

Mohajer, M., Khameneh, B., and Tafaghodi, M. (2014). Preparation and Characterization of PLGA Nanospheres Loaded with Inactivated Influenza Virus, CpG-ODN and Quillaja Saponin. Iran J. Basic Med. Sci. 17, 722. doi:10.22038/ijbms.2014.3340

Moin, I. (2020). Tackling COVID-19 with Nanotechnology. J. Nanomed Nanotechnol 11, 10224. doi:10.35248/2157-7439.20.10.544

Morales-Narváez, E., and Dincer, C. (2020). The Impact of Biosensing in a Pandemic Outbreak: COVID-19. Biosens. Bioelectron. 163, 112274. doi:10.1016/j.bios.2020.112274

Morse, J. S., Lalonde, T., Xu, S., and Liu, W. R. (2020). Learning from the Past: Possible Urgent Prevention and Treatment Options for Severe Acute Respiratory Infections Caused by 2019-nCoV. ChemBioChem 21, 730-738. doi:10.1002/cbic.202000047

Murugan, D., Bhatia, H., Sai, V. V. R., Satija, J., and Fab, P. (2020). P-FAB: A FiberOptic Biosensor Device for Rapid Detection of COVID-19. Trans. Indian Natl. Acad. Eng. 5, 211-215. doi:10.1007/s41403-020-00122-w

Nagatani, N., Tanaka, R., Yuhi, T., Endo, T., Kerman, K., Takamura, Y., et al. (2006). Gold Nanoparticle-Based Novel Enhancement Method for the 
Development of Highly Sensitive Immunochromatographic Test Strips. Sci. Technol. Adv. Mater. 7, 270-275. doi:10.1016/j.stam.2006.02.002

Nam, J. M., Thaxton, C. S., and Mirkin, C. A. (2003). Nanoparticle-based Bio-Bar Codes for the Ultrasensitive Detection of Proteins. Science 301, 1884. doi:10.1126/science. 1088755

Nano the Magazine for Small Science (2020). Rapid Nano-Gold Tests Can Ease Pressure on Centralised Testing for COVID-19. Available at: https://nanomagazine.com/news/2020/3/26/rapidnano-gold-tests-can-ease-pressure-oncentralised-testing-for-covid-19.

Naqvi, S. Z., Kiran, U., Ali, M. I., Jamal, A., Hameed, A., Ahmed, S., et al. (2013). Combined Efficacy of Biologically Synthesized Silver Nanoparticles and Different Antibiotics against Multidrug-Resistant Bacteria. Ijn 8, 3187-3195. doi:10.2147/IJN.S49284

Nasrollahzadeh, M., Sajjadi, M., Soufi, G. J., Iravani, S., and Varma, R. S. (2020). Nanomaterials and Nanotechnology-Associated Innovations against Viral Infections with a Focus on Coronaviruses. Nanomaterials 10, 1072. doi:10.3390/nano10061072

Nazari, M., Xi, M., Lerch, S., Alizadeh, M. H., Ettinger, C., Akiyama, H., et al. (2017). Plasmonic Enhancement of Selective Photonic Virus Inactivation. Sci. Rep. 7 (1), 11951. doi:10.1038/s41598-017-12377-5

Nguyen, A. H., and Sim, S. J. (2015). Nanoplasmonic Biosensor: Detection and Amplification of Dual Bio-Signatures of Circulating Tumor DNA. Biosens. Bioelectron. 67, 443-449. doi:10.1016/j.bios.2014.09.003

Novavax Advances Development of Novel COVID-19 Vaccine (2020). Novavax Inc IR Site. Available at: https://ir.novavax.com/news-releases/news-releasedetails/novavaxadvances-development-novel-covid-19-vaccine (Accessed July $24,2020)$

Osminkina, L. A., Timoshenko, V. Y., Shilovsky, I. P., Kornilaeva, G. V., Shevchenko, S. N., Gongalsky, M. B., et al. (2014). Porous Silicon Nanoparticles as Scavengers of Hazardous Viruses. J. Nanopart. Res. 16, 2430.

Ou, X., Liu, Y., Lei, X., Li, P., Mi, D., Ren, L., et al. (2020). Characterization of Spike Glycoprotein of SARS-CoV-2 on Virus Entry and its Immune Cross-Reactivity with SARS-CoV. Nat. Commun. 11, 1620.

Ozma, M. A., Maroufi, P., Khodadadi, E., Köse, Ş., Esposito, I., Ganbarov, K., et al. (2020). Clinical Manifestation, Diagnosis, Prevention and Control of SARS-CoV-2 (COVID-19) during the Outbreak Period. Le Infez Med. 28 (2), 153-165.

Pati, R., Shevtsov, M., and Sonawane, A. (2018). Nanoparticle Vaccines against Infectious Diseases. Front. Immunol. 9, 2224. doi:10.3389/ fimmu.2018.02224

Pearson, R. M., Casey, L. M., Hughes, K. R., Wang, L. Z., North, M. G., Getts, D. R., et al. (2017). Controlled Delivery of Single or Multiple Antigens in Tolerogenic Nanoparticles Using Peptide-Polymer Bioconjugates. Mol. Ther. 25, 1655. doi:10.1016/j.ymthe.2017.04.015

Pelaz, B., Alexiou, C., Alvarez-Puebla, R. A., Alves, F., Andrews, A. M., Ashraf, S., et al. (2017). Diverse Applications of Nanomedicine. ACS Nano 11, 2313. doi:10.1021/acsnano.6b06040

Pereira, S. O., Barros-Timmons, A., and Trindade, T. (2014). Biofunctionalisation of Colloidal Gold Nanoparticles via Polyelectrolytes Assemblies. Colloid Polym. Sci. 292, 33. doi:10.1007/s00396-013-3037-3

Petrova-Brodskaya, A. V., Bondarenko, A. B., Timin, A. S., Plotnikova, M. A., Afanas'Ev, M. V., Semenova, A. A., et al. (2017). Comparison of Influenza A Virus Inhibition In Vitro by siRNA Complexes with Chitosan Derivatives, Polyethyleneimine and Hybrid Polyarginine-Inorganic Microcapsules. Voprosy virusologii 62, 259-265. doi:10.18821/0507-4088-2017-62-6259-265

Pierantoni, A., Esposito, M. L., Ammendola, V., Napolitano, F., Grazioli, F., Abbate, A., et al. (2015). Mucosal Delivery of a Vectored RSV Vaccine Is Safe and Elicits Protective Immunity in Rodents and Nonhuman Primates. Mol. Ther. - Methods Clin. Dev. 2, 15018. doi:10.1038/mtm.2015.18

Polizzi, K. M. (2019). "Biosensors," in Comprehensive Biotechnology. doi:10.1016/ B978-0-44464046-8.00060-4

Qiu, G., Gai, Z., Tao, Y., Schmitt, J., Kullak-Ublick, G. A., and Wang, J. (2020). Dual-Functional Plasmonic Photothermal Biosensors for Highly Accurate Severe Acute Respiratory Syndrome Coronavirus 2 Detection. ACS Nano 14, 5268-5277. doi:10.1021/acsnano.0c02439

Raghav, R., and Srivastava, S. (2016). Immobilization Strategy for Enhancing Sensitivity of Immunosensors: L -Asparagine-AuNPs as a Promising
Alternative of EDC-NHS Activated Citrate-AuNPs for Antibody Immobilization. Biosens. Bioelectron. 78, 396. doi:10.1016/j.bios.2015.11.066

Raha, S., Mallick, R., Basak, S., and Duttaroy, A. K. (2020). Is Copper Beneficial for COVID-19 Patients? Med. Hypotheses 142, 109814. doi:10.1016/ j.mehy.2020.109814

Reiss, D. R. (2020). The Covid-19 Vaccine Dilemma. Public Health. doi:10.1016/ j.puhe.2021.01.009

Richardson, S., Hirsch, J. S., Narasimhan, M., Crawford, J. M., McGinn, T., Davidson, K. W., et al. (2020). Presenting Characteristics, Comorbidities, and Outcomes Among 5700 Patients Hospitalized with COVID-19 in the New York City Area. JAMA 323, 2052-2059. doi:10.1001/jama.2020.6775

Rogers, J. V., Parkinson, C. V., Choi, Y. W., Speshock, J. L., and Hussain, S. M. (2008). A Preliminary Assessment of Silver Nanoparticle Inhibition of Monkeypox Virus Plaque Formation. Nanoscale Res. Lett. 3, 129-133. doi:10.1007/s11671-008-9128-2

Rojas, M., Rodríguez, Y., Monsalve, D. M., Acosta-Ampudia, Y., Camacho, B., Gallo, J. E., et al. (2020). Convalescent Plasma in Covid-19: Possible Mechanisms of Action. Autoimmun. Rev. 19, 102554. doi:10.1016/ j.autrev.2020.102554

Salleh, A., Naomi, R., Utami, N. D., Mohammad, A. W., Mahmoudi, E., Mustafa, N., et al. (2020). The Potential of Silver Nanoparticles for Antiviral and Antibacterial Applications: A Mechanism of Action. Nanomaterials 10, 1566. doi:10.3390/nano10081566

Santoshi, V., Shakila Banu, A., and Kurian, G. A. (2015). Synthesis, Characterization and Biological Evaluation of Iron Oxide Nanoparticles Prepared by Desmodium gangeticum Root Aqueous Extract. Int. J. Pharm. Pharm. Sci. 7, 75-80.

Sathiyavimal, S., Vasantharaj, S., Bharathi, D., Saravanan, M., Manikandan, E., Kumar, S. S., et al. (2018). Biogenesis of Copper Oxide Nanoparticles (CuONPs) Using Sida Acuta and Their Incorporation over Cotton Fabrics to Prevent the Pathogenicity of Gram Negative and Gram Positive Bacteria. J. Photochem. Photobiol. B: Biol. 188, 126-134. doi:10.1016/ j.jphotobiol.2018.09.014

Savrasova, E. A., Kivero, A. D., Shakulov, R. S., and Stoynova, N. V. (2011). Use of the Valine Biosynthetic Pathway to Convert Glucose into Isobutanol. J. Ind. Microbiol. Biotechnol. 38, 1287. doi:10.1007/s10295-010-0907-2

Sekimukai, H., Iwata-Yoshikawa, N., Fukushi, S., Tani, H., Kataoka, M., Suzuki, T., et al. (2020). Gold Nanoparticle-Adjuvanted S Protein Induces a strong Antigenspecific IgG Response against Severe Acute Respiratory SyndromeRelated Coronavirus Infection, but Fails to Induce Protective Antibodies and Limit Eosinophilic Infiltration in Lungs. Microbiol. Immunol. 64, 33-51. doi:10.1111/1348-0421.12754

Seo, G., Lee, G., Kim, M. J., Baek, S.-H., Choi, M., Ku, K. B., et al. (2020). Rapid Detection of COVID-19 Causative Virus (SARS-CoV-2) in Human Nasopharyngeal Swab Specimens Using Field-Effect Transistor-Based Biosensor. ACS Nano 14 (4), 5135-5142. doi:10.1021/acsnano.0c02823

Sharifi, M., Attar, F., Saboury, A. A., Akhtari, K., Hooshmand, N., Hasan, A., et al. (2019). Plasmonic Gold Nanoparticles: Optical Manipulation, Imaging, Drug Delivery and Therapy. J. Controlled Release 311-312, 170. doi:10.1016/ j.jconrel.2019.08.032

Sharma, G., Kumar, A., Sharma, S., Naushad, M., Prakash Dwivedi, R., ALOthman, Z. A., et al. (2019). Novel Development of Nanoparticles to Bimetallic Nanoparticles and Their Composites: A Review. J. King Saud Univ. - Sci. 14, 1533. doi:10.1016/j.jksus.2017.06.012

Sheng, L., and Christopher Am, M. (2016). HHS Public Access. Physiol. Behav. 176, 100-106. doi:10.1016/j.gde.2016.03.011

Shereen, M. A., Khan, S., Kazmi, A., Bashir, N., and Siddique, R. (2020). COVID-19 Infection: Emergence, Transmission, and Characteristics of Human Coronaviruses. J. Adv. Res. 24, 91-98. doi:10.1016/j.jare.2020.03.005

Siddiqi, K. S., Husen, A., and Rao, R. A. K. (2018). A Review on Biosynthesis of Silver Nanoparticles and Their Biocidal Properties. J. Nanobiotechnology 16, 14. doi:10.1186/s12951-018-0334-5

Sim, W., Barnard, R. T., Blaskovich, M. A. T., and Ziora, Z. M. (2018). Antimicrobial Silver in Medicinal and Consumer Applications: A Patent Review of the Past Decade (2007-2017). Antibiotics 7, 93. doi:10.3390/ antibiotics7040093 
Singh, P., Pandit, S., Mokkapati, V. R. S. S., Garg, A., Ravikumar, V., and Mijakovic, I. (2018). Gold Nanoparticles in Diagnostics and Therapeutics for Human Cancer. Int. J. Mol. Sci. 19, 1979. doi:10.3390/ijms19071979

Singh, P. (2014). Surface Plasmon Resonance. doi:10.1007/978-981-10-6156-1_109 Siordia, J. A. (2020). Epidemiology and Clinical Features of COVID-19: A Review of Current Literature. J. Clin. Virol. 127, 104357. doi:10.1016/j.jcv.2020.104357

Sivasankarapillai, V. S., Pillai, A. M., Rahdar, A., Sobha, A. P., Das, S. S., Mitropoulos, A. C., et al. (2020). On Facing the SARS-Cov-2 (COVID-19) with Combination of Nanomaterials and Medicine: Possible Strategies and First Challenges. Nanomaterials 10, 852. doi:10.3390/nano10050852

Skirtach, A. G., Muñoz Javier, A., Kreft, O., Köhler, K., Piera Alberola, A., Möhwald, H., et al. (2006). Laser-induced Release of Encapsulated Materials inside Living Cells. Angew. Chem. - Int Ed 45, 4612. doi:10.1002/ anie. 200504599

South Korean Government (2020). A Kit for the Qualitative Test of COVID-19 Antibody by Immunochromatography. Available at: https://sugentech.com/ products/productsview.php? $\mathrm{ct}=7 \&$ target $=32 \% 27$.

Speshock, J. L., Murdock, R. C., Braydich-Stolle, L. K., Schrand, A. M., and Hussain, S. M. (2010). Interaction of Silver Nanoparticles with Tacaribe Virus. J. Nanobiotechnology 8, 19. doi:10.1186/14773155-8-19

Storhoff, J. J., Elghanian, R., Mucic, R. C., Mirkin, C. A., and Letsinger, R. L. (1998). One-pot Colorimetric Differentiation of Polynucleotides with Single Base Imperfections Using Gold Nanoparticle Probes. J. Am. Chem. Soc. 120, 1959-1964. doi:10.1021/ja972332i

Sulkowski, M. S., Sherman, K. E., Dieterich, D. T., Bsharat, M., Mahnke, L., Rockstroh, J. K., et al. (2013). Combination Therapy with Telaprevir for Chronic Hepatitis C Virus Genotype 1 Infection in Patients with HIV a Randomized Trial. Ann. Intern. Med. 159, 86. doi:10.7326/0003-4819-159-2201307160-00654

Suresh, L., Brahman, P. K., Reddy, K. R., and J.S., B. (2018). Development of an Electrochemical Immunosensor Based on Gold Nanoparticles Incorporated Chitosan Biopolymer Nanocomposite Film for the Detection of Prostate Cancer Using PSA as Biomarker. Enzyme Microb. Tech. 112, 43. doi:10.1016/ j.enzmictec.2017.10.009

Szunerits, S., Barras, A., Khanal, M., Pagneux, Q., and Boukherroub, R. (2015). Nanostructures for the Inhibition of Viral Infections. Molecules 20, 14051. doi:10.3390/molecules200814051

Thanh Le, T., Andreadakis, Z., Kumar, A., Gómez Román, R., Tollefsen, S., Saville, M., et al. (2020). The COVID-19 vaccine development landscape. Nat Rev Drug Discov. 19, 305-306. doi:10.1038/d41573-020-00073-5

Tahir ul Qamar, M., Alqahtani, S. M., Alamri, M. A., and Chen, L.-L. (2020). Structural Basis of SARS-CoV-2 3CLpro and Anti-COVID-19 Drug Discovery from Medicinal Plants. J. Pharm. Anal. 10, 313-319. doi:10.1016/ j.jpha.2020.03.009

Tanaka, R., Yuhi, T., Nagatani, N., Endo, T., Kerman, K., Takamura, Y., et al. (2006). A Novel Enhancement Assay for Immunochromatographic Test Strips Using Gold Nanoparticles. Anal. Bioanal. Chem. 385, 1414-1420. doi:10.1007/ s00216-006-0549-4

Thi, E. P., Mire, C. E., Lee, A. C. H., Geisbert, J. B., Zhou, J. Z., Agans, K. N., et al. (2015). Lipid Nanoparticle siRNA Treatment of EbolavirusMakona-Infected Nonhuman Primates. Nature 521, 362. doi:10.1038/nature14442

Tebas, P., Yang, S., Boyer, J. D., Reuschel, E. L., Patel, A., Christensen-Quick, A., and Humeau, L. M. (2021). Safety and Immunogenicity of INO-4800 DNA Vaccine Against SARS-CoV-2: A Preliminary Report of an Open-Label, Phase 1 Clinical Trial. EClinicalMedicine 31, 100689.

Trends in It Value (2008). Trends Report.

Tymm, C., Zhou, J., Tadimety, A., Burklund, A., and Zhang, J. X. J. (2020). Scalable COVID-19 Detection Enabled by Lab-On-Chip Biosensors. Cell Mol Bioeng 13, 1-17. doi:10.1007/s12195-020-00642-z

U. S. National Library of Medicine (2020a) Safety and Immunogenicity Study of 2019-nCoV Vaccine (mRNA-1273) for Prophylaxis SARS CoV-2 Infection (COVID-19). US Natl Libr. Med.

Uskoković, Vuk. (2020). Why Have Nanotechnologies Been Underutilized in the Global Uprising against the Coronavirus Pandemic? Nanomedicine 15, 1719-1734.

U. S. National Library of Medicine (2020b). A Phase II Clinical Trial to Evaluate the Recombinant Vaccine for COVID-19 (Adenovirus Vector) - Full Text View -
ClinicalTrials.Gov. Available at: https://clinicaltrials.gov/ct2/show/ NCT04341389 (Accessed July 24, 2020)

Vance, M. E., Kuiken, T., Vejerano, E. P., McGinnis, S. P., Hochella, M. F., and Hull, D. R. (2015). Nanotechnology in the Real World: Redeveloping the Nanomaterial Consumer Products Inventory. Beilstein J. Nanotechnol 6, 1769-1780. doi:10.3762/bjnano.6.181

Vaze, N., Pyrgiotakis, G., McDevitt, J., Mena, L., Melo, A., Bedugnis, A., et al. (2019). Inactivation of Common Hospital Acquired Pathogens on Surfaces and in Air Utilizing Engineered Water Nanostructures (EWNS) Based Nanosanitizers. Nanomedicine Nanotechnology, Biol. Med. 18, 234. doi:10.1016/j.nano.2019.03.003

Vítezslav (2020). TITL.

Walls, A. C., Park, Y.-J., Tortorici, M. A., Wall, A., McGuire, A. T., and Veesler, D. (2020). Structure, Function and Antigenicity of the SARS-CoV-2 Spike Glycoprotein. Cell 181, 281. doi:10.1101/2020.02.19.956581

Wang, Q., Zhang, Y., Wu, L., Niu, S., Song, C., Zhang, Z., et al. (2020). Structural and Functional Basis of SARS-CoV-2 Entry by Using Human ACE2. Cell 181: 894-904.

Weiss, C., Carriere, M., Fusco, L., Capua, I., Regla-Nava, J. A., Pasquali, M., et al. (2020). Toward Nanotechnology-Enabled Approaches against the COVID-19 Pandemic. ACS Nano 14, 6383. doi:10.1021/acsnano.0c03697

WHO (2020). Modes of Transmission of Virus Causing COVID-19: Implications for IPC Precaution Recommendations. Geneva: World Heal Organ.

WHO (2011). WHO Information for Molecular Diagnosis of Influenza Virus in Humans - Update. Who.

Woo, P. C. Y., Lau, S. K. P., Huang, Y., and Yuen, K.-Y. (2009). Coronavirus Diversity, Phylogeny and Interspecies Jumping. Exp. Biol. Med. (Maywood) 234, 1117-1127. doi:10.3181/0903-MR-94

Wu, R., Wang, L., Kuo, H.-C. D., Shannar, A., Peter, R., Chou, P. J., et al. (2020). An Update on Current Therapeutic Drugs Treating COVID-19. Curr. Pharmacol. Rep. 6, 56-70. doi:10.1007/s40495-020-00216-7

Wu, Y. Q. (2007). Improvement of HBV IgM Piezo-Immunosensor with Gold Nanoparticles. Yadian Yu Shengguang/Piezoelectrics Acoustooptics.

Xiang, D., Z, Y., D, W., L, X., Y, J., S, S., et al. (2013). Inhibition of A/Human/ Hubei/3/2005 (H3N2) Influenza Virus Infection by Silver Nanoparticles In Vitro and In Vivo. Int. J. Nanomedicine 8, 4103-4113. doi:10.2147/ IJN.S53622

Xiang, D., Zheng, C.-1., Zheng, Y., Li, X., Yin, J., O' Conner, M., et al. (2013). Inhibition of A/Human/Hubei/3/2005 (H3N2) Influenza Virus Infection by Silver Nanoparticles In Vitro and In Vivo. Ijn 8, 4103. doi:10.2147/ ijn.s53622

Xiao, F., Tang, M., Zheng, X., Liu, Y., Li, X., and Shan, H. (2020). Evidence for Gastrointestinal Infection of SARS-CoV-2. Gastroenterology 158, 1831-1833. doi:10.1053/j.gastro.2020.02.055

Xie, M., and Chen, Q. (2020). Insight into 2019 Novel Coronavirus - an Updated Interim Review and Lessons from SARS-CoV and MERS-CoV. Int. J. Infect. Dis. 94, 119-124. doi:10.1016/j.ijid.2020.03.071

Yadavalli, T., and Shukla, D. (2017). Role of Metal and Metal Oxide Nanoparticles as Diagnostic and Therapeutic Tools for Highly Prevalent Viral Infections. Nanomedicine: Nanotechnology, Biol. Med. 13, 219-230. doi:10.1016/ j.nano.2016.08.016

Yan, R., Zhang, Y., Li, Y., Xia, L., Guo, Y., and Zhou, Q. (2020). Structural Basis for the Recognition of SARS-CoV-2 by Full-Length Human ACE2. Science 367, 1444-1448. doi:10.1126/science.abb2762

Yang, X. X., Li, C. M., and Huang, C. Z. (2016). Curcumin Modified Silver Nanoparticles for Highly Efficient Inhibition of Respiratory Syncytial Virus Infection. Nanoscale 8:3040-3048.

Yen, M.-Y., Schwartz, J., King, C.-C., Lee, C.-M., and Hsueh, P.-R. (2020). Recommendations for Protecting against and Mitigating the COVID-19 Pandemic in Long-Term Care Facilities. J. Microbiol. Immunol. Infect. 53, 447-453. doi:10.1016/j.jmii.2020.04.003

Yusuf, M., Baroroh, U., Hasan, K., Rachman, S. D. S. D., Ishmayana, S., Subroto, T., et al. (2020). No Title. J. Biol. Chem. doi:10.16309/j.cnki.issn.1007-1776.2003.03.004

Zainol Rashid, Z., Othman, S. N., Abdul Samat, M. N., Ali, U. K., and Wong, K. K. (2020). Diagnostic Performance of COVID-19 Serology Assays. Malays J. Pathol. 42 (1), 13-21.

Zhang, J.-n., Wang, W.-j., Peng, B., Peng, W., Zhang, Y.-s., Wang, Y.-l., et al. (2020). Potential of Arbidol for Post-exposure Prophylaxis of COVID-19 
Transmission: A Preliminary Report of a Retrospective Cohort Study. Curr. Med. Sci. 40 (3), 480-485. doi:10.1007/s11596-020-2203-3

Zhang, W., Dixon, M. B., Saint, C., Teng, K. S., and Furumai, H. (2018). Electrochemical Biosensing of Algal Toxins in Water: The Current State-OfThe-Art. ACS Sens. 3, 1233. doi:10.1021/acssensors.8b00359

Zhang, Y., Chen, C., Chen, C., Zhu, S., Shu, C., Wang, D., et al. (2020). Isolation of 2019-nCoV from a Stool Specimen of a Laboratory-Confirmed Case of the Coronavirus Disease 2019 (COVID-19). China CDC Wkly 2, 123. doi:10.46234/ ccdcw2020.033

Zhao, H., Zhou, J., Zhang, K., Chu, H., Liu, D., Poon, V. K.-M., et al. (2016). A Novel Peptide with Potent and Broad-Spectrum Antiviral Activities against Multiple Respiratory Viruses. Sci. Rep. 6, 22008. doi:10.1038/srep22008

Zhao, V. X. T., Wong, T. I., Zheng, X. T., Tan, Y. N., and Zhou, X. (2020). Colorimetric Biosensors for point-of-care Virus Detections. Mater. Sci. Energ. Tech. 3, 237. doi:10.1016/j.mset.2019.10.002

Zhao, Z., Cui, H., Song, W., Ru, X., Zhou, W., and Yu, X. (2020). A Simple Magnetic Nanoparticles-Based Viral RNA Extraction Method for Efficient Detection of SARS-CoV-2. bioRxiv, 518055. doi:10.1101/2020.02.22.961268

Zhou, L., Mao, H., Wu, C., Tang, L., Wu, Z., Sun, H., et al. (2017). Label-free Graphene Biosensor Targeting Cancer Molecules Based on Non-covalent Modification. Biosens. Bioelectron. 87:701-707. doi:10.1016/j.bios.2016.09.025
Zhou, P., Yang, X.-L., Wang, X.-G., Hu, B., Zhang, L., Zhang, W., et al. (2020). A Pneumonia Outbreak Associated with a New Coronavirus of Probable Bat Origin. Nature 579, 270-273. doi:10.1038/s41586-020-2012-7

Zhuang, J., Yin, J., Lv, S., Wang, B., and Mu, Y. (2020). Advanced "Lab-On-A-Chip" to Detect Viruses - Current Challenges and Future Perspectives. Biosens. Bioelectron. 163, 112291. doi:10.1016/j.bios.2020.112291

Łoczechin, A., Séron, K., Barras, A., Giovanelli, E., Belouzard, S., Chen, Y-T., et al. (2019). Functional Carbon Quantum Dots as Medical Countermeasures to Human Coronavirus. ACS Appl. Mater. Inter. 11, 42964-42974.

Conflict of Interest: The authors declare that the research was conducted in the absence of any commercial or financial relationships that could be construed as a potential conflict of interest.

Copyright (c) 2021 Shehu, Auwal, Musa, Mukhtar, Yusuf, Yau, Muhammad, Baba Dala, Sani, Ahmad and Islam. This is an open-access article distributed under the terms of the Creative Commons Attribution License (CC BY). The use, distribution or reproduction in other forums is permitted, provided the original author(s) and the copyright owner(s) are credited and that the original publication in this journal is cited, in accordance with accepted academic practice. No use, distribution or reproduction is permitted which does not comply with these terms. 